\title{
A HISTÓRIA INDÍGENA NO BRASIL E EM MATO GROSSO DO SUL ${ }^{1}$
}

JORGE EREMITES DE OLIVEIRA ${ }^{2}$

$U F G D$

RESUMO: Neste artigo o autor analisa a história indígena no contexto da historiografia produzida no Brasil e no estado de Mato Grosso do Sul. Apresenta o surgimento e o desenvolvimento desta tendência historiográfica a partir da década de 1990 e suas principais características no Programa de Pós-Graduação em História (PPGH) da Universidade Federal da Grande Dourados (UFGD). Também apresenta discussões teórico-metodológicas sobre a etno-história e suas possibilidades de aplicação para o conhecimento da história dos povos indígenas na América do Sul.

PALAVRAS-CHAVE: Etno-história; História Indígena; Historiografia Brasileira.

ABSTRACT: In this article the author analyses the indigenous history in the context of the historiography produced in Brazil and the State of Mato Grosso do Sul. It is presented the emerging and development of this historiographical trend from the 1900s and its main features in the Postgraduate Program in History (PPGH) of the Universidade Federal da Grande Dourados (UFGD). It is also presented theoretical and methodological discussions on the ethnohistory and its possibilities of application to the knowledge of the history of indigenous peoples in South America.

KEYWORDS: Ethnohistory; Indigenous History; Brazilian Historiography.

\footnotetext{
${ }^{1}$ Este trabalho foi iniciado em 2008, mas por razões diversas não pôde ser concluído anteriormente. Muitas das discussões aqui feitas começaram com dois artigos outrora publicados e pouco divulgados ao grande público (EREMITES DE OLIVEIRA, 2001 e 2003), os quais foram revisitados para esta publicação. Na oportunidade, registro meus agradecimentos a todos os colegas com quem tenho mantido interlocução nos últimos anos acerca da história indígena e da etno-história, sobretudo os professores, alunos e ex-alunos do Programa de Pós-Graduação em História da Universidade Federal da Grande Dourados (UFGD).

${ }_{2}^{2}$ Professor e pesquisador da Universidade Federal de Pelotas (UFPel) e bolsista de produtividade em pesquisa do CNPq. E-mail: eremites@hotmail.com .
}

Espaço Ameríndio, Porto Alegre, v. 6, n. 2, p. 178-218, jul./dez. 2012. 
Quem conta hoje a história de Mato Grosso do Sul não tem o direito de colocar o início da colonização na chegada do conquistador europeu, quer este seja de origem espanhola, quer portuguesa. Tanto o Planalto como o Pantanal estavam ocupados desde muitos milênios. Populações variadas tinham chegado a estes espaços e desenvolvido técnicas, estruturas sociais e culturas adaptadas aos diversos ambientes (SCHMITZ, 1998, p. 205).

Até fins da década de 1980, após o fim do regime militar (19641985) e o início do processo de (re) democratização do Brasil, praticamente não se ouvia falar em história indígena ou etno-história na academia em Mato Grosso do Sul. Tampouco havia uma graduação ou um programa de pós-graduação onde estudos dessa natureza pudessem ser desenvolvidos e estimulados. Ocorre que naquele tempo os povos indígenas ainda não tinham despertado a atenção de muitos historiadores nesta parte do Centro-Oeste, diferentemente do que ocorre nos dias de hoje. Soma-se a isso o fato de não haver antropólogos atuando nas instituições de ensino superior existentes no estado, tampouco um número expressivo de mestres e doutores em história ou em campos afins trabalhando continuamente com pesquisas e orientando jovens estudantes. Situação semelhante também é verificada em outras regiões do país para a época, onde as instituições de ensino superior surgiram mais recentemente, na segunda metade do século $X X$.

Mas a partir dos anos 1990 houve uma interessante mudança neste cenário. Arqueólogos que passaram a atuar no estado se depararam com uma gama cada vez maior de fontes escritas e referências bibliográficas de interesse para suas pesquisas. Eram vários tipos de documentos, desde relatos do século XVI, como os conhecidos Naufrágios y Comentários, de Álvar Núñez Cabeza de Vaca (1984 [1555]), e Viaje al Río de la Plata (1534-1554), de Ulrich Schmidel (1903 [1599]), até estudos de antropólogos renomados como Alfred Métraux (1942 e 1963), Claude Lévi-Strauss (1996 [1955]), Darcy Ribeiro (1986 [1980]), Fernando Altenfelder Silva (1949), Max Schmidt (1942 [1905]) e Roberto Cardoso de Oliveira (1968 e 1976), dentre outros. A questão que intrigava os arqueólogos, especialmente os mais jovens, era: o que fazer com tantas fontes e como usá-las em seus estudos? 
Foi então que o arqueólogo jesuíta Pedro Ignacio Schmitz, coordenador do Programa Arqueológico do Mato Grosso do Sul (19852001) - a partir do qual foram desenvolvidos o Projeto Alto Sucuriú (1985-1990) e o Projeto Corumbá (1989-2001) -, ex-diretor do Instituto Anchietano de Pesquisas (IAP), órgão ligado à Universidade do Vale do Rio dos Sinos (UNISINOS), de São Leopoldo, Rio Grande do Sul, incentivou e orientou a realização de pesquisas etno-históricas e afins para a região do Pantanal. Assim o fez com o propósito, também, de entender o registro arqueológico do passado pré-colonial dos povos indígenas na região. Dos dois projetos mencionados, o segundo foi o mais profícuo neste aspecto, do qual participei entre 1989 e 1996, inicialmente como bolsista de iniciação científica na Universidade Federal de Mato Grosso do Sul (UFMS), no antigo Centro Universitário de Corumbá (CEUC), posteriormente rebatizado de Campus do Pantanal (CPAN), e depois como pesquisador colaborador junto ao IAP.

Mais que isso, Schmitz orientou e coorientou várias dissertações de mestrado sobre o assunto, além de ter apoiado a realização de algumas teses de doutorado. Dessa forma, contribuiu para a formação de jovens arqueólogos e etno-historiadores no Sul do país, conforme analisado em publicação anterior (EREMITES DE OLIVEIRA, 2008). Os estudos de Ana Lúcia Herberts (1998), Jorge Eremites de Oliveira (1995 e 2002), José Luis dos Santos Peixoto (1995 e 2002), Magna Lima Magalhães (1999), Maria Eunice Jardim Schuch (1995) e Maribel Girelli (1994) são algumas das monografias que orientou, coorientou e/ou apoiou na década de 1990 e meados dos anos 2000. Publicou ainda diversos trabalhos sobre a arqueologia de Mato Grosso do Sul e, com isso, deu maior visibilidade à história pré-colonial e colonial dos povos indígenas no estado ${ }^{3}$. Daí entender sua posição constante na epígrafe deste trabalho, na qual critica a ideia de que a história dos seres humanos em Mato Grosso do Sul começaria com a chegada dos europeus a esta parte da bacia platina.

Em 1992, passei a trabalhar como pesquisador colaborador, na condição de bolsista de aperfeiçoamento científico da Coordenação de Aperfeiçoamento de Pessoal de Nível Superior (CAPES), junto ao IAP e a cursar disciplinas como aluno especial no curso de mestrado do

\footnotetext{
${ }^{3}$ Ver, por exemplo, Schmitz (1997, 1998 e 2002) e Schmitz et al (1998).
} 
Programa de Pós-Graduação em História da UNISINOS, criado em 1987. Naquela universidade tive aulas com o próprio Schmitz, além de ter iniciado uma disciplina com o antropólogo Bartomeu Melià, também jesuíta, em minha opinião a maior autoridade viva sobre etnologia e etno-história dos povos indígenas de língua guarani. À época Melià orientava vários colegas, dentre os quais Graciela Chamorro (1993), autora de um importante estudo sobre os Kaiowá da comunidade de Panambizinho, localizada no município sul-mato-grossense de Dourados.

Naquele tempo, o IAP, juntamente com o Programa de PósGraduação em História da Pontifícia Universidade Católica do Rio Grande do Sul (PUCRS), eram dois dos mais pujantes espaços para pesquisas arqueológicas e etno-históricas no Sul do país. Por ali era possível vez e outra encontrar Antonio Jacó Brand, falecido recentemente, em $03 / 07 / 2012$, aos 62 anos de idade, um dos principais etnohistoriadores de Mato Grosso do Sul e autor de uma dissertação de mestrado e de uma tese de doutorado marcantes do ponto de vista da etnologia, do indigenismo e da historiografia regionais (BRAND, 1993 e 1997; EREMITES DE OLIVEIRA et al, 2012). Foi por instituições de pesquisa e ensino superior do Rio Grande do Sul, portanto, que passaram vários pesquisadores que depois vieram a trabalhar em universidades sediadas em Mato Grosso do Sul: Antonio Jacó Brand, Antonio Dari Ramos, Bartomeu Melià, Beatriz dos Santos Landa, Graciela Chamorro, José Luis dos Santos Peixoto, Protásio Paulo Langer e outros. Brand, aliás, desde a década de 1990, se estabeleceu como docente na Universidade Católica Dom Bosco (UCDB), outrora Faculdades Unidas Católicas de Mato Grosso (FUCMAT), em Campo Grande, onde em 1995 participou da criação do Núcleo de Estudos e Pesquisas das Populações Indígenas (NEPPI). Lá ministrava aulas, realizava estudos sobre história indígena e coordenava ações voltadas, principalmente, para a garantia de direitos e à conquista da autonomia de comunidades Guarani e Kaiowá estabelecidas no sul do estado. Seu falecimento, até certo ponto precoce, deixou uma grande lacuna nos estudos sobre história indígena, etnologia e indigenismo na região.

No Anchietano, a principal mestre que tive em etno-história foi a professora Ítala Irene Basile Becker, quem pacientemente ouvia minhas 
dúvidas relativas às pesquisas que desenvolvia sobre os Guató e prestava importantíssimas orientações de caráter metodológico ${ }^{4}$. Com ela aprendi uma técnica interessante de fazer fichamento de fontes e bibliografias e, de certa maneira, a realizar uma leitura a contrapelo e produzir alguma etnografia a partir de obras e documentos produzidos desde o século XVI. Trata-se de uma pesquisadora com larga experiência em arqueologia, mas que pela saúde fragilizada havia passado a se dedicar mais à etno-história no Rio Grande do Sul, haja vista as dificuldades de participar dos trabalhos de campo referentes aos projetos arqueológicos desenvolvidos pela equipe do IAP, coordenados por Schmitz.

Dito isso, tenho a dizer que em minha opinião a história indígena em Mato Grosso do Sul não teve um grande impulso inicial a partir do trabalho de historiadores "natos", mas, principalmente, pela influência de um arqueólogo (Pedro Ignacio Schmitz) - e sua equipe -, de um antropólogo (Bartomeu Melià) e de um etno-historiador (Antonio Jacó Brand). Os dois primeiros pesquisadores são sacerdotes da Companhia de Jesus e à época estavam ligados ao Programa de Pós-Graduação em História da UNISINOS, onde orientaram e influenciaram muitos jovens pesquisadores. O terceiro, por sua vez, vinha de uma longa e exitosa experiência no indigenismo, o que também o aproximava de Melià, quem desde muito tempo tem atuação destacada nesta área, sobretudo no Paraguai. Poderia ainda falar dos professores que tive na PUCRS, como Arno Alvarez Kern, José Joaquim Justiniano Proenza Brochado e Klaus Peter Kristian Hilbert, mas isso aumentaria por demais o tamanho deste trabalho. Contudo, registro aqui que eles também têm parcela de contribuição para o desenvolvimento da arqueologia e da etno-história no Brasil, cada um a sua maneira e em seu tempo.

Anos depois, em 1996, regressei para Mato Grosso do Sul, desta vez como docente da UFMS no antigo campus de Dourados, mais conhecido como CEUD (Centro Universitário de Dourados), atual UFGD. Tinha planos de seguir com minhas pesquisas arqueológicas, etnoarqueológicas e etno-históricas na região do Pantanal. Pensava até que tinha alguma expertise sobre os povos indígenas de língua guarani,

\footnotetext{
${ }^{4}$ Ver, por exemplo, Becker (1976, 1984 e 1992) e Eremites de Oliveira (1995 e 1996).
} 
pois havia tido aulas com nada mais nada menos que Bartomeu Melià. Estava enganado, e muito.

Logo que me estabeleci em Dourados, ao ir jogar um saco de lixo no contêiner que havia em frente ao condomínio onde morava, depareime com uma família indígena, provavelmente Kaiowá, a revirar o lugar em busca sabe-se lá do que. Aquela cena me chamou a atenção e fiquei a perguntar-me do que se tratava. Como imaginar que pessoas que vinham de uma sociedade de abundância, tal qual descrita em fontes da época colonial, conforme analisado de maneira brilhante por Melià (1992), estariam naquela situação? Cenas semelhantes, marcadas pela instigante presença indígena em cidades sul-mato-grossenses, também chamaram a atenção de alguns colegas historiadores. Foi o que aconteceu com Cláudio Alves de Vasconcelos, quem se fez questionamentos semelhantes sobre a situação de famílias Terena que comercializavam produtos de suas roças e outros nas cidades de Aquidauana e Anastácio. Suas inquietações o levaram a fazer uma pesquisa sobre os povos indígenas na antiga Província de Mato Grosso e a concluir uma tese de doutorado em história, publicada em fins da década de 1990 (VASCONCELOS, 1999).

De todo modo, segui com minhas pesquisas arqueológicas na universidade. Por vezes alguns colegas da história passavam pelo Laboratório de Arqueologia, atual Laboratório de Arqueologia, Etnologia e Etno-história (ETNOLAB), e faziam alguma insinuação jocosa sobre os "caquinhos" de cerâmica e as "pedrinhas" que estava a analisar. DiziaIhes que aquilo era como um documento para os arqueólogos, tais quais os "velhos papéis" com que trabalham os historiadores, uma vez que também são registros da presença humana e da materialidade de relações sociais em determinados lugares e períodos.

O fato mais importante é que em Dourados conheci e estabeleci interlocução com historiadores dispostos a ir além da experiência de ensino na graduação. Esses colegas constituíram um grupo coeso e a partir daí - não necessariamente nesta ordem - protagonizaram várias atividades importantes na UFMS: estruturação do Centro de Documentação Regional (desde 1983); criação e periodicidade da revista Fronteiras (1997); oferecimento de cursos de especialização em história (como em 1991, 1992, 1996, 1998 e 2002); participação na fundação 
da seção regional da ANPUH (Associação Nacional de História), em 1985; organização de eventos científicos (semanas acadêmicas, encontros regionais etc.); orientação cada vez maior de alunos em nível de iniciação científica; conclusão de seus cursos de doutorado e intensificação da produção intelectual; etc. Dito de outra maneira: protagonizaram a constituição de uma Intelligentia e criaram condições favoráveis - lembrando uma forma de planejamento estratégico - para a elaboração da proposta de criar em Dourados, então o principal campus da UFMS no interior do estado, um curso de mestrado em história. Este foi um passo importante que, posteriormente, também somou em um processo mais amplo, ligado ao movimento de criação e implantação, em 2005 e 2006, respectivamente, da própria UFGD.

Foi assim que em 1998 elaboramos a proposta do Programa de Pós-Graduação em História (PPGH) no antigo CEUD, contendo uma única área de concentração, em História, Região e Identidades, e três linhas de pesquisa: 1) História Indígena; 2) História, Poder e Instituições; 3) Região, Identidades e Representações. Essas linhas abrigavam as pesquisas e expectativas dos docentes participantes do programa. Hoje em dia, contudo, as duas últimas linhas de pesquisa foram reformuladas em função de mudanças no quadro docente, passando à seguinte situação: 2) Movimentos Sociais e Instituições; 3) Fronteiras, Identidades e Representações.

Inicialmente, alguns colegas pensavam em área de concentração e linhas de pesquisa como "história social" e "história econômica", mais ou menos nos moldes de certos programas mais antigos existentes no Sudeste. Não obstante, ao recebermos uma consultoria ad hoc para a elaboração do projeto de programa de pós-graduação, sobretudo a feita pela professora Margarida de Souza Neves, da Pontifícia Universidade Católica do Rio de Janeiro (PUC-RJ), passamos a reelaborar a proposta a partir da valorização de nossas próprias experiências e da realidade sócio-histórica e historiográfica do estado. Foi então que surgiu a ideia de termos uma linha de pesquisa em história indígena em um mestrado em história, algo que era ao mesmo tempo ousado e inovador no âmbito da historiografia brasileira. A proposta do PPGH foi aprovada pela CAPES no segundo semestre de 1998 e no ano seguinte, em 1999, tiveram início as aulas com a primeira turma de mestrandos. Embora na 
ocasião ainda não tivesse concluído o curso de doutorado, coube a mim a elaboração da proposta da linha de pesquisa em história indígena.

$\mathrm{Na}$ verdade, ainda não sabíamos muito bem, de um ponto de vista mais epistemológico, o que seria e o que não seria a história indígena, mas tínhamos uma grande vontade de acertar coletivamente. Alguns colegas que tinham trabalhado nas interfaces da história com a antropologia e a arqueologia, por exemplo, se dispuseram a somar com a linha e a orientar os primeiros alunos. Este foi o caso de Cláudio Alves de Vasconcelos, Gilson Rodolfo Martins, Marina Evaristo Wenceslau, Osvado Zorzato e alguns outros.

De lá para cá são mais de dez anos de uma experiência que se mostrou exitosa sob muitos aspectos, cuja análise mais aprofundada sobre o tema renderia, certamente, ao menos uma boa dissertação de mestrado ou uma tese de doutorado. Mesmo assim, algumas reflexões sobre o assunto têm sido feitas nos últimos anos, conforme atestado nos trabalhos de Eremites de Oliveira (2001), Silva Roiz (2010), Cavalcante (2011) e Queiroz (2011), dentre outras publicações.

São dessas experiências, portanto, que partem muitas das reflexões que aqui faço. Para alguns cientistas sociais mais ortodoxos, elas podem lembrar uma espécie de ego-história ou autoetnografia. Isso ocorre devido, principalmente, ao uso que faço de minha memória sobre o assunto e de escrever na primeira pessoa do singular, algo que não seria estranho à luz de uma antropologia interpretativa. Meu propósito, todavia, é tratar da história indígena no Brasil e dar "maior visibilidade" a uma parte da produção historiográfica sul-mato-grossense, especialmente a do PPGH/UFGD, necessidade esta já apontada por Queiroz (2001, p. 178) e outros colegas. Assim, desenvolvo a presente análise a partir do olhar de quem não está em um grande centro metropolitano, mas que percebe a produção intelectual sobre a história indígena a partir do interior do país, como que por meio da observação de movimentos historiográficos que são, ao mesmo tempo, centrípetos e centrífugos. Ocorre que, obviamente, tendemos a pensar e a valorizar mais a história no Brasil a partir do Sudeste e Sul do que do CentroOeste, Norte e Nordeste, o que de certa maneira pode denotar certa relação de poder existente na academia brasileira. 
Do encobrimento da América ao descobrimento da história indígena no Brasil

Como é de amplo conhecimento, no dia 12 de outubro de 1492, o navegador genovês Cristóvão Colombo e seus comandados, a serviço do Rei da Espanha e embarcados nas caravelas Santa Maria, Pinta e Niña, chegaram a Guanahani, atual ilha de São Salvador, nas Antilhas, América Central. Este fato histórico bastante conhecido é tido como um divisor de águas na história mundial. Ficou registrado na historiografia eurocêntrica e evolucionista como a data oficial do descobrimento da América. Sob outra perspectiva histórica e historiográfica, poder-se-ia afirmar que aquele foi o início de um longo, violento e interminável processo de conquista e colonização do continente americano, também conhecido a partir de então como Novo Mundo. Isso porque os europeus não conquistaram e colonizaram terras desabitadas por seres humanos, mas sim regiões com grande diversidade étnica e cultural onde há muito viviam milhões de pessoas organizadas em sociedades das mais diversas e complexas do ponto de vista social, político, econômico, cosmológico etc. Essas pessoas passaram a ser chamadas de índios, pois inicialmente os espanhóis pensaram que haviam chegado à Índia e não a um continente até então desconhecido por eles, a partir do qual passaram a observar e conhecer melhor a si mesmos.

Mas se no passado o termo "índio" foi atribuído por engano aos habitantes nativos das Américas, hoje em dia expressa certa identidade comum ou indianidade para os povos originários que aqui habitam.

Estudos feitos por arqueólogos e bioantropólogos indicam que os antepassados mais antigos dos indígenas americanos chegaram a esta parte do mundo pelo Estreito de Bering, provavelmente entre 20.000 e 12.000 anos atrás, quando ali às vezes se formava uma espécie de ponte de terra e gelo que ligava a Sibéria, na Ásia, ao Alasca, na América do Norte. O início do povoamento humano das Américas ocorreu durante uma época glacial conhecida como pleistoceno superior, de clima mais frio e seco se comparado com o de hoje, quando o nível do mar era muito mais baixo em relação ao atual, entre 80 a $110 \mathrm{~m}$ apenas no Estreito de Bering (PROUS, 1992 e 1999; NEVES, 1997 e 2000; SILVA 
e RODRIGUES-CARVALHO, 2006; NEVES e PILO, 2008). Há ainda arqueólogos que sustentam a tese de que essa antiguidade pode atingir uns 40.000 anos ou mais, assunto este que ainda gera muitas polêmicas e coloca em xeque, também, relações de poder na arqueologia em nível mundial.

O fato é que quase oito anos depois da chegada dos primeiros espanhóis à América, o almirante português Pedro Álvares Cabral e seus comandados lusitanos, a serviço do Rei de Portugal, desembarcaram em praias localizadas no atual litoral do estado da Bahia, na região Nordeste do Brasil. Este outro fato histórico, ocorrido oficialmente em 22 de abril de 1500 , é tido pela mesma historiografia de matriz eurocêntrica e evolucionista como a data oficial do descobrimento do Brasil.

Nota-se até aqui o emprego do termo historiografia eurocêntrica e evolucionista para se referir a uma historiografia que tem, pois, na trajetória dos povos europeus o seu epicentro espaço-temporal, quer dizer, o eixo pelo qual se percebe, especialmente por meio da cientificidade construída no Ocidente a partir do lluminismo, toda a história da humanidade. Seria como se a Europa fosse o sol, o astro-rei, e os demais continentes os planetas que giram ao seu redor. Significa dizer que o uso deste termo vai para além da ideia de historiografia tradicional, haja vista que este tipo de produção intelectual se opõe diretamente ao que Melià (1992 e 1997) apropriadamente chamou de encobrimento da América. A este tipo de situação, penso que seria mais apropriado chamar de historiografia colonialista, pois este encobrimento tem a ver com múltiplas estratégias de deliberadamente ignorar e omitir o fato de os indígenas serem atores sociais plenos. E mais, que são sujeitos e protagonistas da história deste continente desde muitos milênios antes dos invasores europeus cruzarem o Atlântico em suas caravelas. No caso do Brasil, excluí-los de qualquer período da história, sobremaneira desde os tempos da América Portuguesa até os dias de hoje, seja do ponto de vista econômico, social, cultural ou político, é simplesmente negar sua existência. Quando isso ocorre por parte de historiadores que se opõem à chamada historiografia tradicional, ou mesmo memorialista, administrativa ou oficial como muitos a percebem, a contradição parece ser ainda maior. 
A crítica apresentada chama a atenção, também, para a necessidade de descolonizar o campo da história e de outras ciências sociais, como defendido, por exemplo, por Frederick Cooper (2005) e Linda Tuhiwai Smith (2005). Uma das formas de se fazer isso é ter uma perspectiva mais crítica frente aos campos do conhecimento constituídos no Ocidente e conhecer e valorizar a produção intelectual feita na América Latina, África, Ásia e Oceania, aproximando a história dos estudos pós-coloniais.

Nesta linha de argumentação, cabe citar algumas ideias de Maria Regina Celestino de Almeida (2010), cuja avaliação sobre os povos indígenas na história das Américas vai ao encontro do ponto de vista aqui defendido:

Os povos indígenas tiveram participação essencial nos processos de conquista e colonização em todas as regiões da América. $\mathrm{Na}$ condição de aliados ou inimigos, eles desempenharam importantes e variados papéis na construção das sociedades coloniais ou pós-coloniais. Foram diferentes grupos nativos do continente americano de etnias, línguas e culturas diversas que receberam os europeus das formas mais variadas e foram todos, por eles, chamados índios. Eram, em sua grande maioria, povos guerreiros, e suas guerras e histórias se entrelaçaram, desde o século $\mathrm{XVI}$, com as guerras e histórias dos colonizadores, contribuindo para delinear seus rumos (CELESTINO DE ALMEIDA, 2010, p. 9).

Com efeito, em 1992, cinco séculos depois da chegada dos primeiros espanhóis ao Novo Mundo, muitos governos e segmentos da sociedade civil organizada de vários países americanos e europeus, setores da mídia nacional e internacional, além de empresas ligadas à indústria cinematográfica, empenharam-se para as comemorações dos 500 anos do descobrimento da América. No ano de 2000, um conjunto de comemorações semelhantes ocorreu no Brasil e ficou conhecido como Brasil 500 anos.

Nas duas ocasiões, em contraposição às comemorações oficiais e não oficiais e com o propósito de estimular o debate e a reflexão sobre os cinco séculos das Américas e do Brasil, respectivamente, antropólogos, arqueólogos, historiadores e outros cientistas sociais 
promoveram profícuas discussões e publicaram importantes estudos sobre o assunto.

No ano de 1992, por exemplo, veio a público o livro História dos Índios no Brasil, organizado por Manuela Carneiro da Cunha (1992). Esta obra constituiu-se em um marco historiográfico - mais para os historiadores e talvez menos para os antropólogos - no que se refere aos estudos sobre a história dos povos indígenas no país. No campo da história, para ser mais específico, vários trabalhos foram publicados a partir de então e os historiadores gradativamente passaram a dar mais atenção ao tema. Exemplo disso tem sido a realização de simpósios temáticos sobre a história indígena nos últimos Simpósios Nacionais de História, promovidos pela Associação Nacional de História (ANPUH), em 2003, 2005, 2007, 2009 e 2011.

Outros estudos publicados depois daquele ano também contribuíram para um maior conhecimento sobre a história indígena no Brasil. Exemplo disso são os livros Índios no Brasil, organizado por Luís Donisete Benzi Grupioni (1994), A temática indígena na escola: novos subsídios para professores de $1^{\circ}$ e $2^{\circ}$ graus, organizado por Aracy Lopes da Silva e Luís Donisete Benzi Grupioni (1995), Negros da terra: índios e bandeirantes nas origens de São Paulo, de John Manuel Monteiro (1995a), e Ensaios em antropologia histórica, de João Pacheco de Oliveira (1999). Obras desse tipo foram das mais divulgadas no país a partir dos anos 1990.

Cumpre ainda mencionar o livro Los indios de Brasil, de Roque de Barros Laraia (1993), publicado na Espanha como parte da Coleção Índios da América, em contexto semelhante, mas sem uma versão para a língua portuguesa. Trata-se de outra obra de valor etnológico e historiográfico para a história indígena, embora pouco conhecida e citada por historiadores brasileiros.

A avaliação apresentada não tem - e tampouco poderia ter - a pretensão de omitir a contribuição de vários trabalhos publicados antes das discussões feitas por ocasião dos cinco séculos do descobrimento da América. Pretende-se tão somente apontar o ano de 1992 como um marco historiográfico importante para os estudos a respeito da história dos povos indígenas no país. Sabe-se que em anos anteriores vários trabalhos foram publicados sobre o assunto, porém nenhum deles foi 
divulgado em um momento tão oportuno e causou tanta influência entre historiadores quanto a História dos índios no Brasil. Exemplo de um estudo mais antigo é $A$ função social da guerra na sociedade Tupinambá, de Florestan Fernandes, publicado pela primeira vez em 1952 e republicado mais recentemente, em 2006. Trata-se de um clássico da antropologia funcionalista que ainda está por ser revisitado por parte, especialmente, daqueles que deram mais importância à leitura dos estudos sociológicos de orientação marxista do autor. Outra obra é a própria coleção Suma etnológica brasileira, editada por Darcy Ribeiro com o propósito de trazer ao publico brasileiro uma versão atualizada do Handbook of South American Indians, de Julian H. Steward, cuja primeira edição é de 1949 e a edição fac-similar de 1963. Dessa coleção foram publicados apenas os três primeiros volumes, sob a coordenação de Berta G. Ribeiro (1987): (1 $\left.{ }^{\circ}\right)$ Etnobiologia; $\left(2^{\circ}\right)$ Tecnologia indígena; e $\left(3^{\circ}\right)$ Arte índia. Não foram publicados os outros quatro volumes previstos para a coletânea: $\left(4^{\circ}\right)$ Etnologia comparada, a ser organizado por Charley Wagley; $\left(5^{\circ}\right)$ Etno-história, a cargo de Carlos Araújo Moreira Neto; $\left(6^{\circ}\right)$ Línguas indígenas, sob a responsabilidade de Aryon Dall'Igna Rodrigues; e $\left(7^{\circ}\right)$ Arqueologia brasileira, a ser coordenado por Betty J. Meggers. Se fosse publicado o $5^{\circ}$ volume, sobre etno-história, quiçá os povos indígenas estariam incorporados há mais tempo ao campo de estudo dos historiadores, o que ainda não se deu por completo no país. Outras publicações podem ainda ser incluídas nesta listagem bastante incompleta, a exemplo de Os índios $e$ a civilização..., de Darcy Ribeiro (1986 [1970]), e O índio na história do Brasil e O índio na cultura brasileira, de Berta G. Ribeiro (1983 e 1987).

Consequentemente, de 1992 em diante o termo história indígena passou a ser cada vez mais recorrente no meio acadêmico, em geral usado para se referir ao estudo a respeito da trajetória histórica e sociocultural dos povos nativos das Américas, desde o período précolonial até os dias de hoje. Nesta concepção mais abrangente, a história indígena tem tido quase que o mesmo sentido lato sensu que o termo etno-história, palavra de origem inglesa recentemente dicionarizada no Brasil, porém muito popular em outros países latinoamericanos, como México, Guatemala e Argentina, e também nos 
Estados Unidos e Canadá (EREMITES DE OLIVEIRA, 2001 e 2003; ALVES DA SILVA e EREMITES DE OLIVEIRA, 2005; CAVALCANTE, 2011).

Soma-se a tudo isso a presença recente e crescente de estudantes indígenas em universidades brasileiras, seja em cursos de graduação, seja em programas de pós-graduação. Esta presença tem aumentado significativamente por meio de políticas afirmativas, implementadas mais intensamente a partir da década de 2000, o que também tem contribuído para um contínuo (re) repensar sobre a história indígena produzida na academia brasileira, como ocorre em estados como Mato Grosso do Sul. Isso porque nesta unidade da Federação está a segunda maior população autodeclarada indígena do país, estimada no Censo de 2010 do Instituto Brasileiro e Geografia e Estatística (IBGE) em 73.295 pessoas. Nela muitos estudantes indígenas cada vez mais frequentam cursos de graduação e programas de pós-graduação, seja em universidades existentes no estado, seja em outras partes do Brasil e do mundo.

\section{De volta com a discussão sobre a etno-história}

Embora este assunto possa parecer impertinente, démodé e até certo ponto incômodo para alguns colegas, entendo que ainda é relevante devido à relevância teórico-metodológica que possui para a produção sobre história indígena. Neste sentido, entendo que a etnohistória não deve ser reduzida à noção de uma história anacrônica, exótica, emic e essencialista dos povos indígenas, tampouco percebida como uma proposta restrita aos povos indígenas outrora estudados quase que exclusivamente por etnólogos. Deve ser compreendida para muito mais além, inclusive como uma perspectiva metodológica interdisciplinar - ou disciplina híbrida como alguns a defendem - que tem por objetivo estudar a história e a cultura de povos e comunidades tradicionais, como os indígenas, quilombolas, ribeirinhos etc. (STURTEVANT, 1968; JIMÉNEZ NÚÑEZ, 1975; CAMARCK, 1979; TRIGGER, 1982 e 1986; SILVA GALDAMES, 1988; MALDI, 1993; EREMITES DE OLIVEIRA, 2001 e 2003; FLÓREZ MALAGÓN, 2002; ALVES DA SILVA e EREMITES DE OLIVEIRA, 2005; GALLOWAY, 2006; CAVALCANTE, 2011). 
No caso em tela, trata-se de coletividades humanas com historicidades e temporalidades particulares, também marcadas por contatos interétnicos, mudanças e continuidades socioculturais deles advindas. Por isso mesmo suas histórias não podem ser compreendidas em torno da etnia em si, mas a partir da percepção de que suas trajetórias estão concatenadas com contextos sócio-históricos e políticos mais amplos.

Nas palavras de Thiago Leandro V. Cavalcante:

De acordo com essa acepção, a etno-história, como método interdisciplinar, é o melhor caminho para se compreender os povos de culturas não-ocidentais a partir de uma perspectiva histórica. Nesse sentido, é dada muita importância às tradições orais e às fontes arqueológicas, que podem oferecer dados bastante valiosos sobre essas culturas, as quais, em sua maioria advêm de tradições ágrafas. A linguística também tem se demonstrado uma valiosa aliada nesse campo de pesquisa, os estudos de linguística histórica são capazes de apresentar diversos aspectos que dificilmente seriam acessados por outras vias [...] (CAVALCANTE, 2011, p. 359).

Ao que se tem conhecimento, o surgimento da etno-história, cuja palavra foi grafada originalmente em inglês como ethnohistory, se deu nos Estados Unidos, a partir da primeira metade do século XX, com os estudos de Clark Wissler (1909). Isso ocorreu em um ambiente científico marcado pelo empenho de Franz Boas em instituir um projeto holístico para a antropologia naquele país. Ele entendia que a antropologia deveria ser uma ciência histórica e, como tal, teria que compreender o ser humano do ponto de vista biológico e comportamental, tanto no tempo quanto no espaço. Por isso o modelo de antropologia que lá implantou - e que ainda hoje está em vigor - é baseado nos clássicos quatro campos (four fields): antropologia sociocultural (social ou cultural), antropologia física ou biológica (bioantropologia), linguística antropológica e arqueologia (BOAS, 2004; STOCKING Jr., 2004; BALÉE, 2009) ${ }^{5}$. Atualmente tem sido apontado um quinto campo da

\footnotetext{
${ }^{5}$ No caso brasileiro, a antropologia sociocultural é comumente chamada de antropologia, sendo este o sentido adotado neste trabalho. Além disso, a antropologia física parece ser o campo menos conhecido por parte de etno-historiadores e antropólogos que aqui atuam. No entanto, ao contrário do que alguns podem imaginar em um primeiro momento, ela não se limita à craniometria e ao uso político que teve na Alemanha com o nazismo. Apenas para exemplificar sua importância, um esqueleto humano analisado por um bioantropólogo pode relevar aspectos importantes da vida em sociedade e do cotidiano das pessoas: sexo, idade aproximada, causa da morte, patologias, dieta alimentar, adaptabilidade ao meio,
}

Espaço Ameríndio, Porto Alegre, v. 6, n. 2, p. 178-218, jul./dez. 2012. 
antropologia de matriz estadunidense, a antropologia aplicada (applied anthropology), o que não tem sido feito sem causar polêmicas. No México, porém, há tempos a etno-história ocupa esta posição e lá existe até um curso de graduação na área oferecido pela Escuela Nacional de Antropología e Historia (ENAH) ${ }^{6}$.

$\mathrm{Na}$ etno-história inaugurada nos Estados Unidos, sob a influência do modelo four fields, a noção de documento, por exemplo, passou a ser ampliada e teve uma dimensão prática para além das fontes escritas oficiais. Interessante notar que isso se deu bem antes dos Annales, movimento iniciado em fins dos anos 1920, principalmente na França. Esta observação se faz necessária porque no Brasil alguns historiadores tendem a pensar que a historiografia mundial gira unicamente em torno da historiografia francesa, postura esta que pode ser criticada como reducionista e, de certo modo, colonizada.

Portanto, em um contexto antropológico marcado pela influência do modelo boasiano implantado na antropologia estadunidense, os estudos etno-históricos passaram a ser feitos, sobretudo a partir da década de 1950, por meio do uso de técnicas, métodos e teorias de vários campos do conhecimento (STURTEVANT, 1968; TRIGGER, 1982). Destaque substancial foi dado aos aportes da antropologia, arqueologia e história, recorridos para fins de levantamento, análise e interpretação de fontes de natureza variada: arqueológica, etnográfica, imagética, linguística, oral, textual etc. A ideia era estudar a história e a cultura dos povos indígenas em uma perspectiva espaço-temporal que começaria desde tempos pré-coloniais e viria até a contemporaneidade. Não obstante, até a dedada de 1960 muitos dos estudos etno-históricos e etnológicos produzidos no âmbito da antropologia americana tiveram o propósito de analisar os processos de aculturação em sociedades indígenas7. Com isso, gradualmente se distanciaram, por exemplo, da antropologia praticada nos grandes centros metropolitanos do Brasil, como é o caso do Museu Nacional, no Rio de Janeiro, onde em 1968 foi criado o Programa de Pós-Graduação em Antropologia Social (PPGAS) da

práticas funerárias etc. Conta ainda com os avanços da genética e suas possibilidades na análise do DNA mitocondrial e do cromossomo Y de populações humanas, bem como sua aplicação no âmbito forense, como no caso da identificação dos restos mortais de Che Guevara, encontrados na Bolívia, em 1997, dentre tantas outras possibilidades.

${ }^{6}$ Ver o link http://www.enah.edu.mx/index.php.

${ }^{7}$ Ver, por exemplo, Valentine (1960).

Espaço Ameríndio, Porto Alegre, v. 6, n. 2, p. 178-218, jul./dez. 2012. 
Universidade Federal do Rio de Janeiro (UFRJ). Esta foi uma tendência bastante comum na antropologia praticada nos Estados Unidos, chamada pejorativamente de culturalista, e em vários países americanos, inclusive no Brasil. No entanto, desde fins daquela década e início dos anos 1970 que o paradigma da aculturação se tornou cada vez mais criticado, obsoleto e anacrônico na antropologia mundial.

Talvez esteja aí o fato de muitos antropólogos brasileiros recusarem o termo etno-história, o qual não pode ser reduzido a uma abordagem "culturalista" ou "estruturalista" da história indígena. A etnohistória é muito maior e mais complexa que isso. Não por menos, portanto, que em minha opinião os historiadores que se dedicam à história de povos e comunidades tradicionais, indígenas ou não, são considerados etno-historiadores.

Com efeito, de um ponto de vista epistemológico, percebo que no Brasil a principal diferença entre história indígena e etno-história reside no fato de a primeira estar mais associada à chamada antropologia histórica ou processualista, ao passo que a segunda - quando percebida - estaria mais vinculada à antropologia de matriz estadunidense. Esta diferença não existe apenas em calorosos debates, principalmente entre antropólogos processualistas e estruturalistas, sobre os quais não vou me delongar na ocasião. Também está presente nas abordagens teórico-metodológicas recorridas na análise de problemas variados relacionados a uma questão central: os contatos interétnicos e as mudanças e continuidades socioculturais deles advindas para os povos indígenas, tal qual tem sido comum na etno-história. Uma questão assim remete a debates que estão longe de serem esgotados, pois têm a ver com a origem e o desenvolvimento da antropologia em várias regiões do país, com questões de natureza epistemológica e também com divergências políticas no interior da academia.

Esses debates também resultam do processo de acumulação de conhecimentos, bem como das anomalias e dos respectivos avanços registrados nas ciências sociais. Soma-se a isso o compromisso que muitos antropólogos brasileiros têm com a defesa dos direitos de minorias étnicas e sociais e a autonomia dos povos indígenas, não raramente em busca da descolonização de sua própria disciplina. Tudo isso ocorre à medida que antropólogos passam a ter maior inserção 
política na sociedade nacional, como ocorre na produção de laudos e em estudos voltados para a identificação e delimitação de terras indígenas e territórios de comunidades remanescentes dos quilombos. Em geral são discussões de grande importância do ponto de vista da interpretação da cultura e da história dos povos indígenas em termos espaço-temporais. De todo modo, muitas controvérsias indicam ainda a existência de uma série de transformações em curso no interior da antropologia, arqueologia e história, dentre outros campos do conhecimento. Essas mudanças gradualmente têm derrubado algumas fronteiras existentes entre disciplinas acadêmicas e pluralizado ainda mais as tradições etnográficas e historiográficas. Ocorre que, como apontou Claude LéviStrauss (1991, p. 33-34), não há como negar que a antropologia - ou etnologia, como é conhecida em alguns países da Europa - e a história possuem o mesmo objeto (a vida social), o mesmo objetivo (compreender o ser humano) e semelhante método. Variam apenas na dosagem dos processos de pesquisa, especialmente em termos sincrônicos e diacrônicos, os quais por vezes se distinguem mais pela escolha de perspectivas complementares do que outra coisa.

No âmbito da academia brasileira, as discussões em torno das fronteiras entre antropologia e história ainda não incorporaram devidamente os aportes da arqueologia, principalmente no que se refere ao estudo de uma história indígena total e contínua. Uma perspectiva assim deveria incluir a cultura material (artefatos), os restos de alimentação humana e outras evidências semelhantes (biofatos) e as paisagens humanizadas (ecofatos) como fontes de pesquisa ${ }^{8}$. Esta situação também decorre do tipo de formação dos antropólogos e historiadores no Brasil: os primeiros mais ligados à antropologia social de tradição britânica ou francesa, e os segundos mais voltados à historiografia francesa. Uma história indígena desse nível também deve perceber a trajetória dos povos indígenas como um transcurso plural de milênios e não apenas como uma trajetória de pouco mais que cinco séculos. Entretanto, existem trabalhos publicados nos últimos anos, como Os povos do alto Xingu: história e memória, organizado por Bruna Franchetto e Michael Heckenberger (2001), que contribuem para a superação do distanciamento entre antropologia, arqueologia e história,

${ }^{8}$ Ver Funari (1988) e Eremites de Oliveira (2004a). 
dentre outros campos. Isso é importante hoje em dia, especialmente pelo fato das duas primeiras disciplinas terem surgido juntas no país e atualmente protagonizarem uma (re) aproximação estratégica, oportuna e inovadora, verificada com a abertura de novos cursos de graduação e programas de pós-graduação. No caso da referida obra, nota-se a divulgação de estudos que interpretam, de maneira concatenada e consistente, dados distintos, porém complementares, de evidências do passado em contextos sócio-históricos específicos, inclusive a respeito da cultura material e da organização sócio-espacial.

Esta possibilidade de diálogo entre as disciplinas tem sido mais comum em países americanos, como Argentina, México e Estados Unidos, e menos frequente no Brasil. Isso indica a necessidade de estarmos mais atentos para as publicações feitas no exterior, inclusive em países localizados abaixo da linha do Equador. Ao contrário do que predomina aqui, naqueles três países a formação inicial de antropólogos é mais voltada para o modelo boasiano dos quatro campos, ao menos em nível de graduação. Esta formação tem possibilitado um diálogo mais profícuo entre antropólogos e profissionais de áreas afins, e o conseguinte desenvolvimento da história indígena, por vezes entendida como a própria etno-história.

No caso brasileiro, um diálogo interdisciplinar desse tipo tem ocorrido mais entre a história cultural de matriz francesa e a antropologia histórica ou processualista, o que não raramente pode ocorrer de maneira anacrônica e sem o devido diálogo que os historiadores há muito deveriam manter com os etnólogos (e viceversa). A crítica aqui apresentada considera que muitos historiadores que trabalham com a história indígena demonstram certo desconhecimento em relação aos aportes metodológicos da antropologia e das teorias antropológicas clássicas e contemporâneas. Em algumas situações eles têm se apropriado de maneira pouco pertinente de conceitos e abordagens daquele tipo de história cultural para analisar a história dos povos indígenas na América do Sul. O tema hibridismo, por exemplo, quando aplicado para encobrir identidades indígenas, pode ser visto como um deles. O problema maior reside no fato de muitos conceitos e abordagens não terem sido formulados a partir de experiências etnográficas entre povos ameríndios, tampouco 
JORGE EREMITES DE OLIVEIRA - A História indígena no Brasil e em Mato Grosso do Sul

de todos eles serem portadores de tão grandes inovações paradigmáticas, como muitos imaginam. Ademais, se na França e em outros países europeus o diálogo teórico e empírico entre antropólogos, arqueólogos e historiadores tem se intensificado desde o movimento dos Annales, no Brasil ele ainda está longe de ser amplamente realizado no interior da academia. De um modo geral, nas universidades brasileiras ainda impera uma espécie de areacentrismo, isto é, a ideia de que determinado campo do conhecimento estaria acima de outros, ou mesmo que seria autossuficiente em si mesmo. Nada mais equivocado quando se evoca a tão propagada ideia de multi, inter e transdisciplinaridade.

Apenas para citar um exemplo dessa problemática, sabemos que para o passado indígena mais antigo, período em que não foram produzidos documentos textuais ou feitas observações diretas sobre os grupos étnicos, a arqueologia é senão a principal possibilidade de investigação real. A afirmativa apresentada não significa que o objeto da arqueologia esteja limitado aos mortos, pois os arqueólogos também estudam as sociedades vivas, ou seja, as contemporâneas, indígenas ou não, como fazem os etnoarqueólogos. Daí compreender, por exemplo, o interesse das três primeiras gerações dos Annales pela cultura material, através da qual o ser humano novamente foi colocado em primeiro plano, conforme se percebe nos ensaios de Adam Schnapp (1976) e Jean Marie Pesez (1993).

Nesta linha de raciocínio, portanto, faz-se necessário deixar explícito que a história indígena aqui defendida possui um caráter marcadamente interdisciplinar, isto é, para além das fronteiras disciplinares, e se opõe a todo tipo de areacentrismo ou fobia em relação a outros campos do saber. Dito de outra maneira, a interdisciplinaridade deve ser deliberadamente perseguida na prática e na teoria da pesquisa científica. No âmbito da academia brasileira, o sucesso de uma proposta assim depende menos de ações institucionais e mais da capacidade dos pesquisadores fazerem escola em seu sentido mais amplo, de estabelecerem uma relação de alteridade com disciplinas afins e de superarem as barreiras impostas pelos departamentos e campos do saber. Mais que um mero discurso acadêmico, para a história indígena, sobretudo se praticada nos centros 
JORGE EREMITES DE OLIVEIRA - A História indígena no Brasil e em Mato Grosso do Sul

tidos como "periféricos", a interdisciplinaridade se apresenta como condição sine qua non e como uma excelente oportunidade para a prática da pesquisa. Por isso seu sucesso exige uma postura aberta à exterioridade científica, à constituição de equipes multidisciplinares e ao desenvolvimento de novos estudos coletivos. Dessa forma será menos difícil captar recursos financeiros junto às agências de fomento, conquistar melhores condições de trabalho (laboratórios, por exemplo), publicar os resultados das investigações realizadas e consolidar grupos de pesquisa e programas de pós-graduação.

\section{A história indígena no PPGH/UFGD}

Conforme explicado inicialmente, foi com uma proposta interdisciplinar - até certo ponto holística e inspirada na etno-história que foi criada, em 1999, a linha de pesquisa em história indígena do Programa de Pós-Graduação em História (PPGH) da UFGD, na época do antigo CEUD/UFMS. Sua característica principal é ser uma linha de pesquisa aberta a estudos que tenham na história dos povos indígenas o principal objeto de investigação. Trata-se, pois, de uma proposta aberta ao diálogo - baseado na alteridade - da história com outros campos do saber, em especial com a antropologia e a arqueologia. Disso já resultou a conclusão de várias dissertações de mestrado e o início de algumas teses de doutorado, cujo assunto foi tema do recente artigo de Silva Roiz (2010), no qual constam dados do período de 19992004 que em parte complementam a análise aqui apresentada.

Para tanto, desde o início o referido programa de pós-graduação, em nível de mestrado até 2010 e com doutorado a partir de 2011, contou com alguma infraestrutura, a qual tem sido ampliada gradualmente. Exemplo disso é a aquisição de livros e periódicos nacionais e estrangeiros, a consolidação do Centro de Documentação Regional e do ETNOLAB. Contou ainda com alunos egressos de cursos de pós-graduação lato sensu em história, os quais foram oferecidos no antigo CEUD, e com a revista Fronteiras, além de docentes dispostos a assumir o projeto. Mais recentemente, os próprios alunos do PPGH 
criaram a revista eletrônica História em Reflexão, uma experiência promissora e bastante exitosa.

Grande parte dos mestrandos em história, ao menos até o ano de 2011 , tem sido oriunda de Mato Grosso do Sul, seguido por estudantes provenientes de outros estados, como Mato Grosso, Paraná, Rio Grande do Sul, São Paulo e Tocantins. Muitos foram bolsistas de iniciação científica durante a graduação, sendo a maioria oriunda de cursos de história, embora tenha havido uma procura por parte de profissionais de áreas afins: ciências sociais, direito, educação artística, educação física, filosofia, comunicação social (jornalismo), pedagogia, psicologia e teologia, dentre outros. Nenhum estrangeiro concluiu dissertação de mestrado sobre história indígena até 2011 , o que de certa forma denota o nível de inserção internacional do PPGH até aquele momento. Contudo, teve no pedagogo e historiador Izaque João (2011), da comunidade Kaiowá de Lagoa Rica ou Panambi, em Douradina, Mato Grosso do Sul, o primeiro indígena a concluir o curso de mestrado, cuja defesa da dissertação foi feita no interior da própria reserva e na presença de dezenas de membros da aldeia.

O PPGH/UFGD também está inserido em um contexto regional bastante singular, pois, como dito antes, nos dias atuais Mato Grosso do Sul é um dos primeiros estados da federação em termos de densidade populacional indígena. Apenas no município de Dourados há mais de 13.500 pessoas na Reserva Indígena de Dourados (aldeias Jaguapiru e Bororo; etnias Guarani, Kaiowá e Terena) e na Terra Indígena Panambizinho (aldeia Panambizinho; etnia Kaiowá), além de em áreas ainda não homologadas pelo Estado Nacional. Esta realidade multiétnica tem chamado a atenção de universidades públicas e privadas, em especial no que se refere a sua inserção no cenário regional, do qual os indígenas fazem parte.

Portanto, pode-se afirmar com segurança que é marcante a presença indígena na história, na cultura e no cotidiano da vida de grande parte da população do estado. Esta presença está explícita nos modos de ser e nas próprias identidades da população sul-matogrossense9. Mas também se faz presente nos problemas políticos,

\footnotetext{
${ }^{9}$ Logo após a criação de Mato Grosso do Sul, em 11/10/1977, na época do regime militar, setores das elites políticas, artistas, intelectuais e imprensa, principalmente de Campo Grande, iniciaram um
} 
econômicos e socioculturais que constituem um desafio a ser enfrentado, na busca de soluções para a violação de direitos dos povos originários, pela sociedade organizada e pelos governos. É neste contexto que especialistas de diversas áreas do conhecimento, como advogados, antropólogos, arqueólogos, educadores, geógrafos, historiadores e outros cientistas sociais, dedicam-se cada vez mais ao estudo de temáticas relacionadas aos povos indígenas, inclusive com vistas à garantia de direitos territoriais, apenas para citar um exemplo.

Esta situação está relacionada, ainda, à necessidade de produzir um maior conhecimento acerca das historicidades e dos sistemas socioculturais pretéritos e contemporâneos dos povos ameríndios, haja vista duas questões centrais. Primeira, o interesse de intervir na sociedade nacional em defesa da autonomia e da garantia dos direitos dos povos indígenas frente ao contexto colonialista regional. Segunda, o fascínio que existe em compreender a história e a cultura dos Outros. Por isso, o que atualmente é uma clara tendência na historiografia sulmato-grossense, também está em consonância com as atuais tendências gerais da historiografia brasileira, pautadas pelo estudo de temas contemporâneos relacionados a múltiplas realidades regionais, sem haver a hegemonia de uma ou outra orientação teóricometodológica. Neste aspecto, aliás, a história indígena produzida em Mato Grosso do Sul está mais centrada na história do tempo presente, diferentemente do que se verifica em outros estados brasileiros, onde muitos estudos são centrados em temporalidades mais antigas, geralmente marcadas por ações do Estado Nacional e das frentes de expansão.

Isto posto, ratifico aqui que o desafio atual da história indígena está em assumir uma perspectiva interdisciplinar, holística e plural para compreender o complexo transcurso histórico e sociocultural dos povos ameríndios. Por um lado, historiadores têm recorrido à antropologia para melhor tratar questões socioculturais (dimensão sociocultural),

\footnotetext{
movimento, de cima para baixo, para a construção de nova identidade para o estado, diferenciando-a da dos cuiabanos de Mato Grosso. Nesse movimento também houve a vinculação de uma suposta identidade sul-mato-grossense à imagem dos antigos índios Guaikuru, retratados por parte da historiografia regional como "bravos" e "guerreiros" pela resistência bélica imposta aos conquistadores espanhóis, portugueses e seus sucessores euroamericanos. Sobre o assunto, ver os estudos produzidos por Zorzato (1998) e Ziliani (2000).
} 
como é o caso das abordagens, concepções e conceitos etnológicos, etnográficos e etno-históricos. Por outro, antropólogos têm igualmente mantido um estreito contato com a história para tratar da historicidade dos povos estudados (dimensão histórica, diacrônica ou processual), bem como a dominar técnicas e métodos para o levantamento e a análise de fontes textuais. Arqueólogos, por seu turno, na condição de especialistas em cultura material, igualmente têm dado maior importância a aportes da antropologia e da história em suas pesquisas sobre populações indígenas pretéritas e contemporâneas, haja vista que suas explicações teóricas quase sempre são baseadas em modelos etnográficos (dimensão etnográfica). A mesma avaliação é válida para trabalhos realizados por arqueólogos sobre educação patrimonial.

Apesar dos avanços registrados no campo da história indígena, ainda é válida a seguinte avaliação feita por Manuela Carneiro da Cunha:

Sabe-se pouco da história indígena: nem a origem, nem as cifras de população são seguras, muito menos o que realmente aconteceu. Mas progrediu-se, no entanto: hoje está mais clara, pelo menos, a extensão do que não se sabe. (CARNEIRO DA CUNHA, 1992, p. 11).

Mais recentemente, a referida autora apresentou outra interessante avaliação sobre o assunto:

A história dos povos indígenas no Brasil está mudando de figura. Até os anos 1970, os índios, supunha-se, não tinham nem futuro, nem passado. Vaticinava-se o fim dos últimos grupos indígenas, deplorava-se sua assimilação irreversível e a sua extinção tida por inelutável diante do capital que se expandia nas fronteiras do país. A ausência de passado, por sua vez, era corroborada por uma dupla reticência, de historiadores e de antropólogos. A reticência dos historiadores era metodológica, e as dos antropólogos, teórica (CARNEIRO DA CUNHA, 2009, p. 125).

Com efeito, os desafios da história indígena assumem maior dimensão à medida que são levadas em consideração não somente as diferentes historicidades, mas também a diversidade sociocultural dos povos indígenas. Significa dizer que os índios são atores sociais e sujeitos ou agentes de sua própria história, e portadores de sistemas socioculturais específicos e complexos. Estas constatações entram em 
choque com o eurocentrismo e o evolucionismo de cunho colonialista, há décadas criticado nas ciências sociais, especialmente a partir dos estudos pós-coloniais, cuja influência ainda marca profundamente a visão dos índios na historiografia brasileira e em muitos cursos de graduação em história existentes no país. Refiro-me a certo modelo adotado para cursos de graduação em história, nos quais muitas vezes consta um número talvez exagerado disciplinas centradas em uma perspectiva evolucionista e eurocêntrica do processo sócio-histórico mundial: história antiga, história medieval, história moderna e história contemporânea. Neste modelo, por vezes chamado de conteudista, muito pouco ou nada se estuda sobre arqueologia, etnologia e história da África, Ásia e Oceania. No caso brasileiro, isso se torna um paradoxo diante da obrigatoriedade de conteúdos sobre a temática história e cultura afro-brasileira e indígena no ensino fundamental e médio, conforme estabelece a Lei $n^{\circ}$. 11.645, de 10/03/2008.

Dessa maneira, como afirmou John Manuel Monteiro (1995b, p. 228), é preciso reescrever páginas inteiras da história do Brasil para que este novo conhecimento sobre o passado possa lançar luz menos pessimista e mais justa sobre o futuro dos povos indígenas. Nos casos em que esses capítulos ainda não foram escritos, a tarefa é mais árdua, porém igualmente fascinante e desafiadora, sobretudo para jovens pesquisadores ávidos por produzir novos conhecimentos, rever antigos paradigmas e transpor velhas fronteiras. Para tanto, é preciso considerar os indígenas como sujeitos históricos plenos e perceber que o tempo histórico é múltiplo e diferenciado, conforme pontuou João Pacheco de Oliveira (1999).

Das tarefas mais urgentes que pesam à história indígena em Mato Grosso do Sul e em outras regiões do país estão aquelas pesquisas que privilegiem a história dos povos indígenas pré, durante e pós-contato com os povos europeus e euroamericanos. Devem enfatizar, dentro da ótica da diversidade e da dinâmica socioculturais, as diferentes historicidades e processos sócio-históricos em termos espaçotemporais. Os estudos podem estar pautados pela perspectiva das indissociáveis práticas socioculturais, ecológicas, econômicas e políticas que marcam a trajetória, a vida e as ações desses povos ao longo de seus transcursos e em uma perspectiva processual. 
No caso do PPGH/UFGD, quatro grandes eixos temáticos têm merecido atenção especial para linha de pesquisa história indígena, pois podem ser desdobrados em muitos outros. Primeiro, as questões ecológicas e socioculturais pertinentes às relações entre povos indígenas e seus respectivos territórios, sobretudo os processos relacionados à dinâmica de ocupação e uso dos recursos naturais, bem como à humanização da natureza. Segundo, os processos de conquista e colonização que causaram desterritorializações, reterritorializações, processos de territorialização, mudanças socioculturais abruptas e tentativas de assimilação de muitos povos indígenas por parte das sociedades envolventes e antecessores europeus. Terceiro, a situação indígena contemporânea e sua relação com as sociedades nacionais e com o próprio Estado, na qual está incluída a atual realidade histórica, sociocultural, política e econômica dos povos indígenas. Quarto, a problemática da forma como as sociedades indígenas são representadas nos relatos de viajantes, missionários etc., bem como na iconografia, na historiografia e na imprensa, e suas repercussões na formação do imaginário e do pensamento historiográfico regional.

No período de 2001 a 2011, apenas para exemplificar, 45 dissertações de mestrado versaram sobre a temática indígena no PPGH/UFGD, sendo que os resumos das monografias defendidas até 2006 e em 2009 foram publicados em trabalhos organizados anteriormente (EREMITES DE OLIVEIRA, 2004b; SILVA, 2007; CHAMORRO, 2009). Este total pode ser quantificado, de modo muito aproximado e generalizante, em termos de temáticas e períodos estudados (povos indígenas, temas gerais etc.), a saber:

A) Povos da família linguística Jê nos séculos XVIII e XIX (Akroá, Xakriabá, Xavante e Xerente juntos) $=1$;

B) Arqueologia (Tradição Tupiguarani, educação escolar indígena e práticas mortuárias desde o período pré-colonial aos dias de hoje) $=3$;

C) Bororo (séculos XVIII-XX) = 2;

D) Guarani ou Ñandeva (séculos $X X-X X I)=2$;

E) Guarani ou Ñandeva e Kaiowá juntos (séculos XX-XXI) = 7;

F) Guarani ou Ñandeva, Kaiowá e Terena juntos - Reserva Indígena de Dourados (séculos $\mathrm{XX}-\mathrm{XXI}$ ) $=2$; 
G) Guarani missioneiro e outros povos indígenas em missões religiosas do período colonial $=3$;

H) Guató (séculos $X X-X X I)=1$;

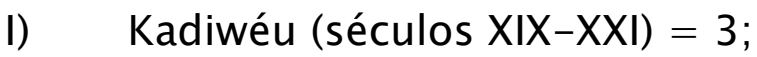

J) Kaiowá (séculos $X X-X X I)=5$;

K) Mbayá-Guaikuru (século XVIII) = 1;

L) Ofaié (séculos $X X-X X I)=1$;

M) Terena (séculos $X I X-X X I)=5$;

$\mathrm{N}) \quad$ Vários povos indígenas juntos em temáticas mais amplas desde o período colonial (movimentos indígenas, missões religiosas no período republicano, educação escolar indígena, cosmologia etc.) $=6$;

O) Guaná (século XIX) = 1;

P) Krahô-Kanela (séculos $X X-X X I)=1$;

Q) Kinikinau (séculos $X X-X X I)=1$.

Os dados apresentados podem ser mais bem visualizados no gráfico abaixo. Das 45 dissertações, 25 (55,6\%) foram defendidas por homens e $20(44,4 \%)$ por mulheres, o que indica que o assunto tem sido do interesse de ambos os sexos. Visto do ponto de vista cronológico, nota-se que $31(68,9 \%)$ dissertações tratam da história indígena situada entre fins do século XIX aos dias de hoje, quer dizer, possuem um recorte cronológico ligado ao que se pode chamar de história do tempo presente. Eis aqui uma tendência historiográfica marcante em Mato Grosso do Sul, o estudo dos povos indígenas atuais, o que difere da produção historiográfica existente em outras unidades da Federação, conforme dito anteriormente e verificado em estudos já mencionados. Com isso, urge a necessidade de conjugar técnicas, métodos e teorias da história e da antropologia, os quais "vão aos poucos desconstruindo compreensões simplistas e interpretações equivocadas sobre os índios e suas relações" (CELESTINO DE ALMEIDA, 2010, p. 10-11).

De um modo geral, 25 (55,6\%) dissertações tratam da história de povos indígenas de língua guarani, tanto de maneira particular como em contextos mais amplos e multiétnicos. Este número sugere a existência de uma tendência em estudar etnias numericamente maiores e com mais visibilidade na história da região platina e de Mato Grosso do Sul. 


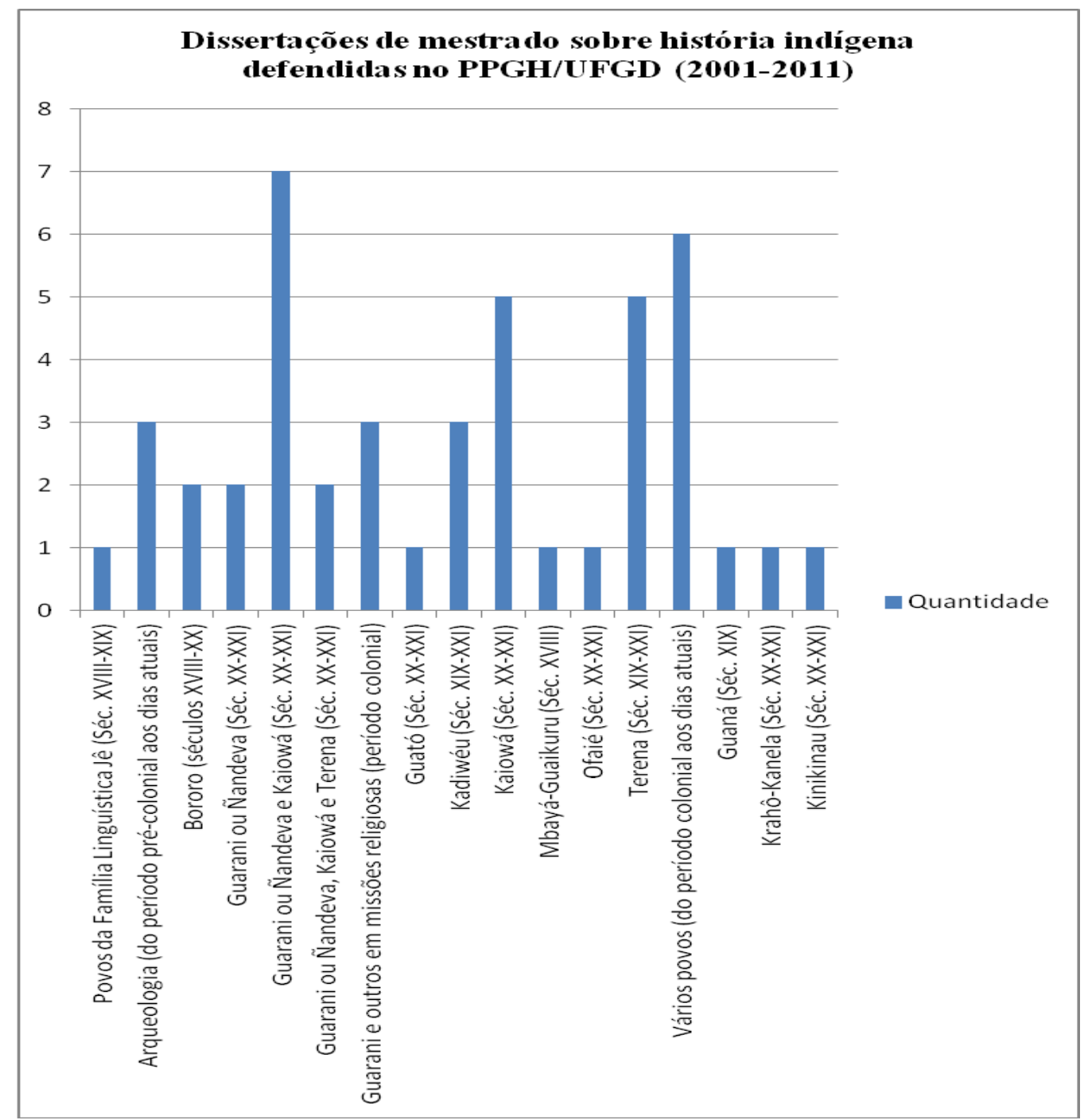

Gráfico 1 - Dissertações de mestrado sobre história indígena defendidas no PPGH/UFGD (2001-2011).

De um modo geral, 25 (55,6\%) dissertações tratam da história de povos indígenas de língua guarani, tanto de maneira particular como em contextos mais amplos e multiétnicos. Este número sugere a existência de uma tendência em estudar etnias numericamente maiores e com mais visibilidade na história da região platina e de Mato Grosso do Sul.

Dito isso, percebe-se que a história indígena no PPGH/UFGD soma a tantas outras iniciativas no Brasil e em outros países de incluir os Outros na historiografia. Contribui, a sua maneira, para mudanças paradigmáticas no campo de produção intelectual dos historiadores, aproximando-o de campos afins, notadamente da antropologia, para 
estudos ligados ao tempo presente, e da arqueologia, para estudos sobre temporalidades mais recuadas.

Cumpre ainda registrar que em fins de 2010 foi aprovado pela CAPES e implantado na UFGD o Programa de Pós-Graduação em Antropologia (PPGAnt), com área de concentração em Antropologia Sociocultural e três linhas de pesquisa: $1^{\text {a }}$ ) Etnicidade, Diversidade e Fronteiras; $2^{\mathrm{a}}$ ) Etnologia, Educação Indígena e Interculturalidade; $3^{\mathrm{a}}$ ) Arqueologia, Etno-história e Patrimônio Cultural. Sua primeira turma de mestrandos ingressou em 2011 e quando este artigo foi finalizado ainda havia sido defendida nenhuma dissertação. Com esta nova situação, esforços têm sido envidados para a cooperação e o diálogo entre o PPGH e o PPGAnt. Isso poderá contribuir ainda mais para aumentar quantitativa e qualitativamente os estudos sobre os povos indígenas e para pluralização de tradições etnográficas e historiográficas. Com isso, se no passado o antigo Sul de Mato Grosso foi uma área importante para a realização de estudos antropológicos, hoje em dia Mato Grosso do Sul também se apresenta como o lugar onde pesquisadores produzem cada vez mais novos conhecimentos sobre os povos indígenas existentes no estado e em outras regiões da América do Sul.

Esta situação chama a atenção para a importância da expansão do ensino superior pelo interior do país, incluindo a abertura de novos cursos de graduação e programas de pós-graduação, a partir dos quais o lócus do conhecimento passa a ser gradualmente descentralizado em relação aos grandes centros metropolitanos. Com isso, mudanças interessantes têm sido registradas no contexto da historiografia nacional, cada vez mais pujante, plural e inovadora sob muitos aspectos.

Em suma, é certo que nunca os povos indígenas estiveram tão presentes no campo dos historiadores quanto nos dias hoje, embora os avanços registrados aqui e acolá ainda possam ser considerados um tanto quanto tímidos. Ou parafraseando Jacques Le Goff (1993, p. 9), definitivamente chegará o momento em que não poderemos mais nos esquivar da história indígena. E como tenho dito amiúde a meus pares mais próximos, ainda que alguns o tentem fazer por meio de um discurso xenófobo frente a outros campos do conhecimento, valendo-se de uma suposta autoridade, pureza e independência do campo da 
história, poderão fazer dessa postura o seu próprio túmulo. Isso porque a preocupação com a história indígena no tempo presente chama a atenção, inevitavelmente, para as interfaces mantidas entre a história e a antropologia. Esta situação faz parte de um contexto maior, marcado pela descolonização das ciências sociais no Ocidente, superação de barreiras disciplinares e construção de novas maneiras de produzir o conhecimento na academia e em outros espaços.

\section{Referências bibliográficas}

ALTENFELDER SILVA, Fernando. Mudança cultural dos Terêna. Revista do Museu Paulista, São Paulo, v. 3, p. 271-380, 1949.

ALVES DA SILVA, Cleube; EREMITES DE OLIVEIRA, Jorge. Fontes textuais e etnoistória: possibilidades de novas abordagens para uma história indígena no estado do Tocantins. Revista do Museu Antropológico, Goiânia, v. 8, n. 1, p. 77-84, 2005.

BALÉE, William. The four-field model of Anthropology in the United States. Amazônica: Revista de Antropologia, Belém, v. 1, n. 1, p. 28-53, 2009.

BECKER, Ítala Irene B. O Índio Kaingáng no Rio Grande do Sul. São Leopoldo: Instituto Anchietano de Pesquisas, 1976. (Pesquisas Antropologia, n. 29).

El indio y la colonización: Charrúas y Minuanos. São Leopoldo: Instituto Anchietano de Pesquisas, 1984. (Série Antropologia, n. 37).

Lideranças indígenas no começo das reduções jesuíticas da Província do Paraguay. São Leopoldo: Instituto Anchietano de Pesquisas, 1992. (Pesquisas Antropologia, n. 47).

BOAS, Franz. Antropologia cultural. Rio de Janeiro: Jorge Zahar Editor, 2004.

BRAND, Antonio Jacó. O confinamento e seu impacto sobre Pãi/Kaiowá. 1993. 276 f. Dissertação (Mestrado em História) - Pontifícia Universidade Católica do Rio Grande do Sul, [1993].

O impacto da perda da terra sobre a tradição Kaiowá/Guarani: os difíceis caminhos da palavra. 1997. 382 f. Tese (Doutorado em História) - Pontifícia Universidade Católica do Rio Grande do Sul, [1997].

CABEZA DE VACA, Álvar N. Naufrágios y Comentários. Madrid: Raycar, 1984. 
CAMARCK, Robert M. Etnohistoria y teoría antropológica. Guatemala: Editorial José de Pineda Ibarra, 1979.

CARNEIRO DA CUNHA, Manuela. Introdução a uma história indígena. In:

(Org.). História dos índios no Brasil. São Paulo: FAPESP/SMC/Companhia das Letras, 1992. p. 9-24.

Cultura com aspas e outros ensaios. São Paulo: Cosac Naify, 2009.

CARDOSO DE OLIVEIRA, Roberto. Urbanização e tribalismo: a integração dos índios Terena numa sociedade de classes. Rio de Janeiro: Zahar, 1968.

Do índio ao bugre: o processo de assimilação dos Terena. Rio de Janeiro: Livraria Francisco Alves, 1976.

CAVALCANTE, Thiago Leandro V. Etno-história e história indígena: questões sobre conceitos, métodos e relevância da pesquisa. História, São Paulo, v. 30, n. 1, p. 349371, jan.-jun. 2011.

CELESTINO DE ALMEIDA, Maria Regina. Os índios na história do Brasil. Rio de Janeiro: Editora FGV, 2010.

CHAMORRO, Graciela. Kurusu Ñe'ëngatu ou palavras que a história não poderia esquecer. 1993. 312 f. Dissertação (Mestrado em História Ibero-Americana) UNISINOS, [1993].

Contribuições para a história indígena contemporânea. História em Reflexão, Dourados, v. 3, n. 6, p. 1-25, jul.-dez. 2009.

COOPER, Frederick. Postcolonial studies and the study of history. In: LOOMBA, Ania et al. (Orgs.). Postcolonial studies and beyond. Durham/London: Duke University Press, 2005. p. 401-422.

EREMITES DE OLIVEIRA, Jorge. Os argonautas Guató: aportes para o conhecimento dos assentamentos e da subsistência dos grupos que se estabeleceram nas áreas inundáveis do Pantanal Matogrossense. 1995. 210 f. Dissertação (Mestrado em História/Arqueologia) - Pontifícia Universidade Católica do Rio Grande do Sul, [1995].

Guató, argonautas do Pantanal. Porto Alegre: EDIPUCRS, 1996.

A História Indígena em Mato Grosso do Sul: dilemas e perspectivas. Territórios \& Fronteiras, Cuiabá, v. 2, n. 2, p. 115-124, 2001.

Da pré-história à história indígena: (re) pensando a arqueologia e os povos canoeiros do Pantanal. 2002. 470 f. Tese (Doutorado em História/Arqueologia) Pontifícia Universidade Católica do Rio Grande do Sul, [2002].

Sobre os conceitos e as relações entre história indígena e etnoistória. Prosa,

Espaço Ameríndio, Porto Alegre, v. 6, n. 2, p. 178-218, jul./dez. 2012. 
Campo Grande, v. 3, n. 1, p. 39-47, 2003. 2004a.

Arqueologia das sociedades indígenas no Pantanal. Campo Grande: Oeste,

(Org.). Dissertações de mestrado defendidas no Programa de Pós-Graduação em História do Campus de Dourados da UFMS (2000-2004). Fronteiras: Revista de História, Dourados, v. 8, n. 15, p. 145-182, jan.-jun. 2004b.

Arqueologia Pantaneira: história e historiografia (1875-2000). Dourados: Editora UFGD, 2008.

EREMITES DE OLIVEIRA, Jorge et al. Autor, obra e meio: apresentando um etnohistoriador. Entrevista com o Prof. Dr. Antonio Jacó Brand. História em Reflexão, Dourados, v. 6, n. 11, p. 1-15, jan.-jun. 2012.

FERNANDES, Florestan. A função social da guerra na sociedade Tupinambá. São Paulo: Globo, 2006.

FLÓREZ MALAGÓN, Alberto G. ¿Antropología histórica, antropohistoria...? 2002. Disponível em: http://javeriana.edu.co/cursos/aflorez/ETNO.htm . Acesso em: 26 set. 2002.

FRANCHETTO, Bruna; HECKENBERGER, Michael (Orgs.). Os povos do Alto Xingu: história e cultura. Rio de Janeiro: Editora UFRJ, 2001.

FUNARI, Pedro Paulo A. Arqueologia. São Paulo: Ática, 1988.

GALlOWAY, Patricia. Practicing ethnohistory. Mining archives, hearing testimony, constructing narrative. Lincoln/London: University of Nebraska Press, 2006.

GIRELLI, Maribel. Lajedos com gravuras na região de Corumbá, MS. 1994. 144 f. Dissertação (Mestrado em História) - UNISINOS, [1994].

GRUPIONI, Luís Donisete B. (Org.). Índios no Brasil. Brasília: MEC, 1994.

HERBERTS, Ana Lúcia. Os Mbayá-Guaycuru: área, assentamento, subsistência e cultura material. 1998. 345 f. Dissertação (Mestrado em História) - UNISINOS, [1998].

JIMÉNEZ NÚÑEZ, Alfredo. Sobre el concepto de etnohistoria. In: Reunión de Antropólogos Españoles, 1, 1975. Anais... Sevilla: Universidad de Sevilla, 1975. p. 91105.

JOÃO, Izaque. Jakaira Reko Nheypyrũ Marangatu Mborahéi: origem e fundamentos do canto ritual Jerosy Puku entre os Kaiowá de Panambi, Panambizinho e Sucuri'y, Mato Grosso do Sul. 2011. 119 f. Dissertação (Mestrado em História) Universidade Federal da Grande Dourados, [2011]. 
LARAIA, Roque de B. Los indios de Brasil. Madrid: Editorial Mapfre, 1993.

LE GOFF, Jacques. Prefácio à nova edição. In: LE GOFF, Jacques (Org.). A História Nova. São Paulo: Martins Fontes, 1993. p. 1-13.

LÉVI-STRAUSS, Claude. Antropologia Estrutural. Rio de Janeiro: Tempo Brasileiro, 1991.

Tristes trópicos. São Paulo: Companhia das Letras, 1996.

MAGALHÃES, Magna L. Payaguá: os senhores do rio Paraguai. 1999. $181 \mathrm{f}$. Dissertação (Mestrado em História) - UNISINOS, [1999].

MALDI, Denise. A teia da memória - proposta teórica para a construção de uma etnohistória. Cuiabá: Editora UFMT, 1993.

MELIÀ, Bartomeu. El encobrimiento de América. Acción, Asunción, n. 102, p. 37-41, 1992.

El Paraguay inventado. Asunción: Centro de Estudios Antonio Guasch, 1997.

MÉTRAUX, Alfred. The native tribes of Eastern Bolivia and Western Mato Grosso. Washington: U. S. Govt. Print. Off, 1942.

Ethnography of the Chaco. In: STEWARD, Julian H. (Org.). Handbook of South American Indians. New York: Cooper Square Publishers, 1963. p. 197-370. v. 1 .

MONTEIRO, John Manuel. Negros da terra: índios e bandeirantes nas origens de São Paulo. São Paulo: Companhia das Letras, 1995a.

O desafio da história indígena no Brasil. In: SILVA, Aracy L.; GRUPIONI, Luiz Donizete B. (Orgs.). A temática indígena na escola. Novos subsídios para professores de $1^{\circ}$ e $2^{\circ}$ graus. Brasília: MEC/MARI/UNESCO, 1995b. p. 221-237.

NEVES, Walter A. (Org.). Dossiê Surgimento do Homem na América. Revista USP, São Paulo, n. 34, jun.-ago.1997.

(Org.). Dossiê Antes de Cabral: Arqueologia Brasileira I e II. Revista USP, São Paulo, n. 44, fev. 2000.

NEVES, Walter A.; PILO, Luis Beethoven. O povo de Luzia: em busca dos primeiros americanos. Rio de Janeiro: Globo, 2008.

PACHECO DE OLIVEIRA, João. Ensaios em antropologia histórica. Rio de Janeiro: Editora UFRJ, 1999. 
PEIXOTO, José Luis dos S. A ocupação Tupiguarani na borda oeste do Pantanal Sul-mato-grossense: maciço de Urucum. 1995. 127 f. Dissertação (Mestrado em História/Arqueologia) - Pontifícia Universidade Católica do Rio Grande do Sul, [1995].

A ocupação dos povos indígenas pré-coloniais nos grandes lagos do Pantanal Sul-mato-grossense. 2002. 262 f. Tese (Doutorado em História/Arqueologia) - Pontifícia Universidade Católica do Rio Grande do Sul, [2002].

PESEZ, Jean-Marie. História da cultura material. In: LE GOFF, Jacques (Org.). A Nova História. São Paulo: Martins Fontes, 1993. p. 177-213.

PROUS, André. Arqueologia Brasileira. Brasília: Editora UnB, 1992.

Povoamento das Américas: um debate sem fim. Ciência Hoje, Rio de Janeiro, v. 25, n. 149 , p. 40-45, maio 1999.

QUEIROZ, Paulo Roberto Cimó. A historiografia sul-mato-grossense, 1968-2010: notas para um balanço. In: GLEZER, Raquel (Org.). Do passado para o futuro: edição comemorativa dos 50 anos da ANPUH. São Paulo: Contexto, 2011. v. 1. p. 167-185.

RIBEIRO, Berta. O índio na história do Brasil. São Paulo: Graal, 1983.

(Org.). Suma Etnológica Brasileira. Petrópolis: Vozes/FINEP, 1987. 3 v.

O índio na cultura brasileira. Rio de Janeiro: UNIBRADE/UNESCO, 1987.

RIBEIRO, Darcy. Kadiwéu: ensaios etnológicos sobre o saber, o azar e a beleza. Petrópolis: Vozes, 1980.

Os índios e a civilização: a integração das populações indígenas no Brasil moderno. Petrópolis: Vozes, 1986.

SCHMIDEL, Ulrich. Viaje al Río de la Plata (1534-1554). Buenos Aires: Cabaut, 1903.

SCHMIDT, Max. Estudos de Etnologia Brasileira: peripécias de uma viagem entre 1900 e 1901. Seus resultados etnológicos. São Paulo: Companhia Editora Nacional, 1942.

SCHMITZ, Pedro Ignacio. Pantanal: os primeiros passos da pré-história. Ciência Hoje, Rio de Janeiro, v. 22, n. 129, p. 36-45, jul. 1997.

Arqueologia em Mato Grosso do Sul: dois projetos, dois resultados. Fronteiras, Campo Grande, v. 2, n. 4, p. 203-223, 1998.

Arqueologia do Pantanal do Rio Paraguai. Revista de Arqueologia Americana, México, n. 21, p. 191-214, 2002. 
SCHMITZ, Pedro Ignacio et al. Aterros indígenas no Pantanal do Mato Grosso do Sul. São Leopoldo: Unisinos, 1998. (Pesquisas Antropologia, n. 54).

SCHNAPP, Adam. A Arqueologia. In: LE GOFF, Jacques; NORA, Pierre (Orgs.). História: novas abordagens. Rio de Janeiro: Francisco Alves, 1976. p. 1-20.

SCHUCH, Maria Eunice J. Xaray e Chané: índios frente à expansão espanhola e portuguesa no Alto-Paraguai. 1995. 87 f. Dissertação (Mestrado em História) UNISINOS, [1995].

SILVA, Aracy L. da; GRUPIONI, Luís Donisete. B. (Orgs.). A temática indígena na escola: novos subsídios para professores de $1^{\circ}$ e $2^{\circ}$ graus. Brasília: MEC/MARI/UNESCO, 1995.

SILVA, Eliazar João da (Org.). Dissertações de mestrado defendidas no Programa de Pós-Graduação em História da Universidade Federal da Grande Dourados (2005-2006). Fronteiras, Dourados, v. 9, n. 16, p. 111-127, jan.-jul. 2007.

SILVA, Hilton P.; RODRIGUES-CARVALHO, Cláudia (Orgs.). Nossa origem: o povoamento das Américas - visões multidisciplinares. Rio de Janeiro: Vieira e Lent, 2006.

SILVA GALDAMES, Osvaldo. ¿Etnohistoria o Historia Indígena? In: SILVA GALDAMES, Osvaldo et al. (Orgs.). Encuentro de etnohistoriadores. Santiago: Universidad de Chile, 1988. p. 7-9.

SILVA ROIZ, Diogo. A população indígena na historiografia de Mato Grosso do Sul: o caso do programa de pós-graduação em História da UFMS, Campus de Dourados. Revista História \& Perspectivas, Uberlândia, v. 23, n. 43, p. 251-302, jul.-dez. 2010.

SMITH, Linda Tuhiwai. Decolonizing methodologies: research and indigenous peoples. London/Dunedin: Zed Books/University of Otago Press, 2005.

STEWARD, Julian H. (Org.). Handbook of South American Indians. New York: Cooper Square Publishers, 1963. v. 1.

STOCKING JR., George W. A formação da antropologia americana, 1883-1911: antologia. Rio de Janeiro: Contraponto/Editora UFRJ, 2004.

STURTEVANT, William C. Anthropology, History, and Ethnohistory. In: CLIFTON, James A. (Org.). Introduction to Cultural Anthropology. Essays in the Scope and Methods of the Science of Man. Boston: Houghton Mifflin Company, 1968. p. 451-475.

TRIGGER, Bruce G. Etnohistory: problems and prospects. Ethnohistory, Chicago, n. 29, p. 1-29, 1982. 253-267, 1986.

Ethnohistory: the unfinished edifice. Ethnohistory, Chicago, v. 33, n. 3, p. 
VALENTINE, Charles A. Uses of ethnography in an acculturation study. Ethnohistory, Chicago, n. 7, p. 1-25, 1960.

VASCONCELOS, Cláudio A. de. A questão indígena na Província de Mato Grosso: conflito, trama e continuidade. Campo Grande: Editora UFMS, 1999.

WISSLER, Clark (Org.). The Indians of Greater New York and the Lower Hudson. New York: Hudson-Fulton Publication/Order of the Trustees, 1909. (Anthropological Papers of the American Museum of Natural History, v. 3). Disponível em: http://digitallibrary.amnh.org/dspace/handle/2246/283 . Acesso em: 28 jun. 2011.

ZILIANI, José Carlos. Tentativas de construções identitárias em Mato Grosso do Sul (1977-2000). 2000. 132 f. Dissertação (Mestrado em História) - Universidade Federal do Mato Grosso do Sul, [2000].

ZORZATO, Osvaldo. Conciliação e Identidade: considerações sobre a historiografia de Mato Grosso (1904-1983). 1998. 181 f. Tese (Doutorado em História) Universidade de São Paulo, [1998]. 
JORGE EREMITES DE OLIVEIRA - A História indígena no Brasil e em Mato Grosso do Sul

Quadro 1 - Dissertações de mestrado sobre história indígena defendidas no PPGH/UFGD (2001-2011).

\begin{tabular}{|c|c|c|c|}
\hline $\mathbf{N}^{\mathbf{o}}$ & Autor/a e Orientador/a & Data de defesa & Título \\
\hline 01 & $\begin{array}{l}\text { Noêmia dos Santos Pereira Moura (autora) } \\
\text { Osvaldo Zorzato (orientador) }\end{array}$ & $14 / 08 / 2001$ & $\begin{array}{l}\text { UNIEDAS: o símbolo da apropriação do protestantismo } \\
\text { norte-americano pelos Terena (1972-1993) } \\
\end{array}$ \\
\hline 02 & $\begin{array}{l}\text { Renata Lourenço Girotto (autora) } \\
\text { Nilce Aparecida da S. F. Fedatto (orientadora) }\end{array}$ & $20 / 08 / 2001$ & $\begin{array}{l}\text { Por uma nova textura histórica: o movimento de } \\
\text { professores indígenas Guarani/Kaiowá em Mato Grosso } \\
\text { do Sul - } 1988 \text { a } 2000\end{array}$ \\
\hline 03 & $\begin{array}{l}\text { Lelian Chalub Amin Paschoalick (autora) } \\
\text { Marina Evaristo Wenceslau (orientadora) }\end{array}$ & $25 / 09 / 2001$ & $\begin{array}{l}\text { A arte dos índios Kaiowá da Reserva Indígena de } \\
\text { Dourados-MS: transformações e permanências, uma } \\
\text { expressão de identidade e afirmação étnica }\end{array}$ \\
\hline 04 & $\begin{array}{l}\text { Aroldo Careaga (autor) } \\
\text { Jérri Roberto Marin (orientador) }\end{array}$ & $27 / 08 / 2001$ & $\begin{array}{l}\text { Salesianos e Bororo nos sertões mato-grossenses (1894- } \\
\text { 1910) }\end{array}$ \\
\hline 05 & $\begin{array}{l}\text { Astor Weber (autor) } \\
\text { Cláudio Alves de Vasconcelos (orientador) }\end{array}$ & $23 / 08 / 2002$ & $\begin{array}{l}\text { Os Eyiguayegui-Mbayá-Guaicuru: encontros e } \\
\text { confrontos com os luso-brasileiros na Capitania de Mato } \\
\text { Grosso }\end{array}$ \\
\hline 06 & $\begin{array}{l}\text { Manuel Pacheco Neto (autor) } \\
\text { Cláudio Alves de Vasconcelos (orientador) }\end{array}$ & $20 / 08 / 2002$ & $\begin{array}{l}\text { Palmilhando o Brasil colonial: a motricidade de } \\
\text { bandeirantes, índios e jesuítas no século XVII }\end{array}$ \\
\hline 07 & $\begin{array}{l}\text { Vera Lúcia Ferreira Vargas (autora) } \\
\text { Gilson Rodolfo Martins (orientador) }\end{array}$ & $15 / 09 / 2003$ & $\begin{array}{l}\text { A construção do território Terena (1870-1966): uma } \\
\text { sociedade entre a imposição e a opção }\end{array}$ \\
\hline 08 & $\begin{array}{l}\text { Adilson Manfrin (autor) } \\
\text { Marina Evaristo Wenceslau (orientadora) }\end{array}$ & $19 / 12 / 2003$ & Loreto (1610-1631): Guyraypotý do Pirapó \\
\hline 09 & $\begin{array}{l}\text { Carlos Alberto dos Santos Dutra (autor) } \\
\text { Gilson Rodolfo Martins (orientador) }\end{array}$ & $09 / 06 / 2004$ & $\begin{array}{l}\text { O território Ofaié pelos caminhos da história: } \\
\text { reencontro e trajetória de um povo }\end{array}$ \\
\hline 10 & $\begin{array}{l}\text { Adilson Crepalde (autor) } \\
\text { Osvaldo Zorzato (orientador) }\end{array}$ & $13 / 06 / 2004$ & O rezador e a história \\
\hline 11 & $\begin{array}{l}\text { Fábio Henrique Cardoso Leite (autor) } \\
\text { Marina Evaristo Wenceslau (orientadora) }\end{array}$ & $16 / 09 / 2004$ & $\begin{array}{l}\text { O Kayowá de Dourados: sua vida espiritual num } \\
\text { contexto histórico }\end{array}$ \\
\hline 12 & $\begin{array}{l}\text { Léia Teixeira Lacerda (autora) } \\
\text { Nanci Leonzo (orientadora) }\end{array}$ & $22 / 06 / 2004$ & $\begin{array}{l}\text { A mulher Terena em tempos de AIDS: um estudo de } \\
\text { caso da Aldeia Limão Verde, município de Aquidauana } \\
\text { - MS }\end{array}$ \\
\hline 13 & Giovani José da Silva (autor) & $23 / 08 / 2004$ & A construção física, social e simbólica da Reserva \\
\hline
\end{tabular}

Espaço Ameríndio, Porto Alegre, v. 6, n. 2, p. 178-218, jul./dez. 2012. 
JORGE EREMITES DE OLIVEIRA - A História indígena no Brasil e em Mato Grosso do Sul

\begin{tabular}{|c|c|c|c|}
\hline & Gilson Rodolfo Martins (orientador) & & $\begin{array}{l}\text { Indígena Kadiwéu (1899-1984): memória, identidade e } \\
\text { história }\end{array}$ \\
\hline 14 & $\begin{array}{l}\text { Neimar Machado de Souza (autor) } \\
\text { Eudes Fernando Leite (orientador) }\end{array}$ & $17 / 09 / 2004$ & $\begin{array}{l}\text { A Redução de Nuestra Señora de La Fé no Itatim: entre } \\
\text { a cruz e a espada (1631-1659) }\end{array}$ \\
\hline 15 & $\begin{array}{l}\text { Rosely Aparecida Stefanes Pacheco (autora) } \\
\text { Osvaldo Zorzato (orientador) }\end{array}$ & $29 / 10 / 2004$ & $\begin{array}{l}\text { Mobilizações guarani Kaiowá e Ñandeva e a (re) } \\
\text { construção de territórios }(1978-2003): \\
\text { perspectivas para o direito indígena }\end{array}$ \\
\hline 16 & $\begin{array}{l}\text { Meire Adriana da Silva (autora) } \\
\text { Cláudio Alves de Vasconcelos (orientador) }\end{array}$ & $05 / 09 / 2005$ & $\begin{array}{l}\text { O movimento dos Guarani e Kaiowá de reocupação e } \\
\text { recuperação de seus territórios em Mato Grosso do Sul e } \\
\text { a participação do Conselho Indigenista Missionário } \\
\text { (CIMI) }\end{array}$ \\
\hline 17 & $\begin{array}{l}\text { Marilene da Silva Ribeiro (autora) } \\
\text { Jorge Eremites de Oliveira (orientador) }\end{array}$ & $23 / 09 / 2005$ & $\begin{array}{l}\text { Uma ilha na história de um povo canoeiro: o processo } \\
\text { de desterritorialização e reterritorialização dos Guató na } \\
\text { região do Pantanal (século XX) }\end{array}$ \\
\hline 18 & $\begin{array}{l}\text { Nely Aparecida Maciel (autora) } \\
\text { Jorge Eremites de Oliveira (orientador) }\end{array}$ & $23 / 09 / 2005$ & $\begin{array}{l}\text { História dos Kaiowá da aldeia Panambizinho: da década } \\
\text { de } 1920 \text { aos dias atuais }\end{array}$ \\
\hline 19 & $\begin{array}{l}\text { Carlos Alberto Panek Junior (autor) } \\
\text { Jorge Eremites de Oliveira (orientador) }\end{array}$ & $29 / 09 / 2006$ & $\begin{array}{l}\text { Sistema de assentamento: uma abordagem para o estudo } \\
\text { da cultura material e grupos étnicos }\end{array}$ \\
\hline 20 & $\begin{array}{l}\text { Lisandra Zago (autora) } \\
\text { Cláudio Alves de Vasconcelos (orientador) }\end{array}$ & $03 / 10 / 2005$ & $\begin{array}{l}\text { Etnoistória Bororo: contatos, alianças e conflitos } \\
\text { (séculos XVIII e XIX) }\end{array}$ \\
\hline 21 & $\begin{array}{l}\text { Marta Coelho Castro Troquez (autora) } \\
\text { Osvaldo Zorzato (orientador) }\end{array}$ & $17 / 08 / 2006$ & $\begin{array}{l}\text { Professores índios e transformações sócio-culturais em } \\
\text { um cenário multiétnico: a Reserva Indígena de } \\
\text { Dourados (1960-2000) }\end{array}$ \\
\hline 22 & $\begin{array}{l}\text { Cleube Alves da Silva (autor) } \\
\text { Jorge Eremites de Oliveira (orientador) }\end{array}$ & $05 / 10 / 2006$ & $\begin{array}{l}\text { Confrontando mundos: os Xerente, Xavante, Xakriabá e } \\
\text { Akroá e os contatos com os conquistadores da Capitania } \\
\text { de Goiás (1749-1851) }\end{array}$ \\
\hline 23 & $\begin{array}{l}\text { Giseli Deprá (autora) } \\
\text { João Carlos de Souza (orientador) }\end{array}$ & $07 / 11 / 2006$ & $\begin{array}{l}\text { O Lago de Itaipu e a luta dos Avá-Guarani pela terra: } \\
\text { representações na imprensa do Oeste do Paraná (1976- } \\
\text { 2000) }\end{array}$ \\
\hline 24 & $\begin{array}{l}\text { Eva Maria Luiz Ferreira (autora) } \\
\text { Levi Marques Pereira (orientador) }\end{array}$ & $30 / 10 / 2007$ & $\begin{array}{l}\text { A participação dos índios Kaiowá e Guarani como } \\
\text { trabalhadores nos ervais da Companhia Mate Laranjeira } \\
(1902-1952)\end{array}$ \\
\hline
\end{tabular}

Espaço Ameríndio, Porto Alegre, v. 6, n. 2, p. 178-218, jul./dez. 2012. 
JORGE EREMITES DE OLIVEIRA - A História indígena no Brasil e em Mato Grosso do Sul

\begin{tabular}{|c|c|c|c|}
\hline 25 & $\begin{array}{l}\text { Lélio Loureiro da Silva (autor) } \\
\text { Jérri Roberto Marin (orientador) }\end{array}$ & $01 / 11 / 2007$ & $\begin{array}{l}\text { As representações dos Kaiowa-Ñandeva no jornal O } \\
\text { Progresso na década de } 1980\end{array}$ \\
\hline 26 & $\begin{array}{l}\text { Luciano Pereira da Silva (autor) } \\
\text { Jorge Eremites de Oliveira (orientador) }\end{array}$ & $17 / 12 / 2007$ & $\begin{array}{l}\text { Arqueologia e Ensino Superior Indígena: uma } \\
\text { experiência na Universidade do Estado de Mato Grosso, } \\
\text { Campus de Barra dos Bugres (2006-2007) }\end{array}$ \\
\hline 27 & $\begin{array}{l}\text { Thiago Leandro Vieira Cavalcante (autor) } \\
\text { Jorge Eremites de Oliveira (orientador) }\end{array}$ & $02 / 06 / 2008$ & $\begin{array}{l}\text { Apropriações e ressignificações do mito de São Tomé } \\
\text { na América: a inclusão do índio na cosmologia cristã }\end{array}$ \\
\hline 28 & $\begin{array}{l}\text { Sônia Maria Couto Pereira (autora) } \\
\text { Jorge Eremites de Oliveira (orientador) }\end{array}$ & $07 / 10 / 2008$ & $\begin{array}{l}\text { Etnografia e iconografia nos registros produzidos por } \\
\text { Hércules Florence durante a Expedição Langsdorff na } \\
\text { Província do Mato Grosso (1826-1829) }\end{array}$ \\
\hline 29 & $\begin{array}{l}\text { Adilson de Campos Garcia (autor) } \\
\text { Osvaldo Zorzato (orientador) }\end{array}$ & $12 / 03 / 2009$ & $\begin{array}{l}\text { A participação dos índios Guaná no desenvolvimento } \\
\text { econômico do Sul de Mato Grosso (1826-1829) }\end{array}$ \\
\hline 30 & $\begin{array}{l}\text { João Flores (autor) } \\
\text { Osvaldo Zorzato (orientador) }\end{array}$ & $01 / 04 / 2009$ & $\begin{array}{l}\text { Muita terra para pouco índio? A formação de fazendas } \\
\text { em território kadiwéu (1950-1984) }\end{array}$ \\
\hline 31 & $\begin{array}{l}\text { Carlos Barros Gonçalves (autor) } \\
\text { Cándida Graciela Chamorro Argüello (orientadora) }\end{array}$ & $30 / 07 / 2009$ & $\begin{array}{l}\text { O movimento ecumênico protestante no Brasil e a } \\
\text { implantação da Missão Caiuá em Dourados }\end{array}$ \\
\hline 32 & $\begin{array}{l}\text { Ana Maria Melo e Souza (autora) } \\
\text { Cándida Graciela Chamorro Argüello (orientadora) }\end{array}$ & $31 / 07 / 2009$ & $\begin{array}{l}\text { Ritual, identidade e metamorfose: representações do } \\
\text { Kunumi Pepy entre os índios Kaiowá da aldeia } \\
\text { Panambizinho }\end{array}$ \\
\hline 33 & $\begin{array}{l}\text { Aline Castilho Crespe Lutti (autora) } \\
\text { Levi Marques Pereira (orientador) }\end{array}$ & $21 / 08 / 2009$ & $\begin{array}{l}\text { Acampamentos indígenas e ocupações: novas } \\
\text { modalidades de organização e territorialização entre os } \\
\text { Guarani e Kaiowá no município de Dourados (1990- } \\
\text { 2009) }\end{array}$ \\
\hline 34 & $\begin{array}{l}\text { Jean Paulo Pereira Menezes (autor) } \\
\text { Osvaldo Zorzato (orientador) }\end{array}$ & $27 / 08 / 2009$ & $\begin{array}{l}\text { Os intelectuais, a política e suas perspectivas: o } \\
\text { CEIMAN e sua contribuição acerca do povo Terena }\end{array}$ \\
\hline 35 & $\begin{array}{l}\text { Matias Belido dos Santos (autor) } \\
\text { Jorge Eremites de Oliveira (orientador) }\end{array}$ & $28 / 08 / 2009$ & $\begin{array}{l}\text { Práticas mortuárias entre povos indígenas no Pantanal } \\
\text { Matogrossense: arqueologia, etno-história e etnologia }\end{array}$ \\
\hline 36 & $\begin{array}{l}\text { Priscila Viudes (autora) } \\
\text { Protásio Paulo Langer (orientador) }\end{array}$ & $31 / 08 / 2009$ & $\begin{array}{l}\text { Índios nas páginas d'O Progresso: representações da } \\
\text { desnutrição indígena no jornal (2005) }\end{array}$ \\
\hline 37 & $\begin{array}{l}\text { Sidiclei Roque Deparis (autor) } \\
\text { Osvaldo Zorzato (orientador) }\end{array}$ & $30 / 10 / 2009$ & $\begin{array}{l}\text { União das Nações Indígenas (UNI): contribuição ao } \\
\text { movimento indígena no Brasil (1980-1988) }\end{array}$ \\
\hline 38 & Carlos Rodrigues Pacheco (autor) & $14 / 08 / 2009$ & A dinâmica territorial e os processos de (re)construção \\
\hline
\end{tabular}

Espaço Ameríndio, Porto Alegre, v. 6, n. 2, p. 178-218, jul./dez. 2012. 
JORGE EREMITES DE OLIVEIRA - A História indígena no Brasil e em Mato Grosso do Sul

\begin{tabular}{|l|l|c|l|}
\hline & Levi Marques Pereira (orientador) & & $\begin{array}{l}\text { da Terra Indígena Jaguapiré Memby em Tacuru/MS: a } \\
\text { ação do Estado es conflitos de interesse entre } \\
\text { indígenas e trabalhadores rurais sem terra (1954-2009) }\end{array}$ \\
\hline 39 & $\begin{array}{l}\text { Aline Maria Müller (autora) } \\
\text { Protásio Paulo Langer (orientador) }\end{array}$ & $\begin{array}{l}\text { Índios Kadiwéu e posseiros na Serra da Bodoquena: } \\
\text { representações na mídia impressa acerca de um conflito }\end{array}$ \\
\hline 40 & $\begin{array}{l}\text { Cássio Knapp (autor) } \\
\text { Antônio Dari Ramos (orientador) }\end{array}$ & $\begin{array}{l}\text { Retórica da educação escolar indígena entre o mesmo e } \\
\text { o diferente }\end{array}$ \\
\hline 41 & $\begin{array}{l}\text { Victor Ferri Mauro (autor) } \\
\text { Jorge Eremites de Oliveira (orientador) }\end{array}$ & $\begin{array}{l}\text { A trajetória dos índios Krahô-Kanela: Etnicidade, } \\
\text { territorialidade e reconhecimentos de direitos territoriais }\end{array}$ \\
\hline 42 & $\begin{array}{l}\text { Izaque João (autor) } \\
\text { Jorge Eremites de Oliveira (orientador) }\end{array}$ & $\begin{array}{l}\text { Jakaira Reko Nheypyrũ Marangatu Mborahéi: origem e } \\
\text { fundamentos do canto ritual Jerosy Puku entre os } \\
\text { Kaiowá de Panambi, Panambizinho e Sucuri'y, Mato } \\
\text { Grosso do Sul }\end{array}$ \\
\hline 43 & $\begin{array}{l}\text { Lenir Gomes Ximenes (autora) } \\
\text { Levi Marques Pereira (orientador) }\end{array}$ & $\begin{array}{l}\text { Terra Indígena Buriti: estratégias e performances terena } \\
\text { na luta pela terra }\end{array}$ \\
\hline 44 & $\begin{array}{l}\text { Lucicleide Gomes dos Santos (autora) } \\
\text { Antônio Dari Ramos (orientador) }\end{array}$ & $\begin{array}{l}\text { Cerâmica Kinikinau: a arte de um povo tido como } \\
\text { extinto }\end{array}$ \\
\hline 45 & $\begin{array}{l}\text { André Luís Freitas da Silva (autor) } \\
\text { Cándida Graciela Chamorro Argüello (orientadora) }\end{array}$ & \begin{tabular}{l} 
Reduçóes Jesuítico-Guarani: espaço da diversidade \\
\hline
\end{tabular}
\end{tabular}

Espaço Ameríndio, Porto Alegre, v. 6, n. 2, p. 178-218, jul./dez. 2012. 
JORGE EREMITES DE OLIVEIRA - A História indígena no Brasil e em Mato Grosso do Sul

Espaço Ameríndio, Porto Alegre, v. 6, n. 2, p. 178-218, jul./dez. 2012. 